\title{
DEBATES
}

\section{Breve história da curadoria de arte em museus}

Brief history of art curation in museums

hitps://doi.org/10.1590/1982-02672021v29e15

\section{ANA GONÇALVES MAGALHÃES'}

https://orcid.org/0000-0002-2291-428X

Universidade de São Paulo / São Paulo, SP, Brasil

\section{HELOUISE COSTA²}

https: / / orcid.org/0000-000 1-6 102-7889

Universidade de São Paulo / São Paulo, SP, Brasil

RESUMO: Este texto busca compreender as narrativas construídas em torno da história da curadoria de arte enquanto prática social, por meio da discussão de alguns de seus paradigmas. Propõe-se uma história na contramão da tendência de abordar a curadoria de arte apenas a partir da segunda metade do século XX. Do cuidado com as coleções às exposições temporárias, a curadoria de arte especializou-se ao longo dos séculos e foi responsável por articular diferentes discursos de legitimação sobre a arte. Se num primeiro momento constituíram-se narrativas sobre a arte e os artistas, ao longo do século XX e das experiências de arte moderna o foco voltou-se para a formação de público e de quadros profissionais para os museus. A partir da década de 1960 ocorre a divisão de uma figura que antes era una: o conservador - ou curador de coleção - e o curador independente. Enquanto o primeiro passou a ser considerado um mero funcionário das instituições museológicas, o segundo ganhou protagonismo e estatuto de autor. A inclusão de experiências curatoriais realizadas no Brasil, em diferentes momentos históricos, serve como

1. Historiadora da arte, Professora Livre-Docente, curadora e diretora do $\mathrm{Mu}$ seu de Arte Contemporânea da Universidade de São Paulo (MAC USP). E-mail: <amagalhaes@usp.br>.

2. Professora Livre-Docente e curadora do MAC USP. E-mail:<helouise@usp.br>. 
contraponto crítico às práticas curatoriais de arte realizadas nas instituições tradicionais europeias e estadunidenses, com vistas a uma abordagem que leve em conta o processo de globalização.

PALAVRAS-CHAVE: Curadoria de arte. Curador de coleção. Curador independente. Museu de arte. Coleção de arte.

ABSTRACT: This article searches to understand the narratives built around the history of art curatorship as a social practice, considering some of its paradigms. We thus propose a counternarrative to the tendency to contend art curatorship only as emerging in the second half of the $20^{\text {th }}$ century. From the conservation of collections to temporary exhibitions, art curatorship has become a specialized field and has been responsible to articulate different discourses of the legitimization in the visual arts throughout the centuries. If in the first period, narratives of the visual arts and of the artists were built, in the $20^{\text {th }}$ century and in face of modern art experiences, the focus was geared towards the education of the audience and of the museum professional staff. Since the 1960s, there has been a separation of a figure that was understood as one professional: the conservator (or collection curator) and the independent curator. In this process, the former has been considered as a mere technical employee of museum institutions, whereas the latter has gained the spotlight and a status as an author/creator. The inclusion of curatorial experiences that took place in Brazil in various historical moments serves as a critical counterpoint to the art curatorial practices in the framework of traditional European and US institutions, aiming at an approach that looks into the issue from the perspective of the globalization process.

KEYWORDS: Art curatorship. Conservator. Independent curator. Art museum. Art collection. 
Nos últimos anos a palavra curadoria passou a designar atividades que envolvem a seleção de produtos ou informações voltados para públicos específicos e elitizados. Curadoria de livros, músicas, comida, moda, notícias e conteúdos digitais fazem parte hoje das estratégias de um mercado que busca conquistar um contingente de público exposto a uma grande diversidade de mercadorias e ao enorme volume de dados disponibilizados pela internet. Na ânsia de se diferenciarem daquilo que consideram o gosto indistinto das massas, os consumidores recorrem a serviços profissionais de curadoria para personalizar suas escolhas de acordo com certos padrões de gosto e com a imagem que buscam construir de si nas redes sociais. Embora esse fenômeno pareça não ter relação direta com o campo da arte, não pode ser desvinculado da ascensão da figura do curador independente, iniciada no final da década de 1960, e de sua valorização pela indústria cultural, além do fenômeno da espetacularização da arte e dos museus, ocorrida em anos recentes. ${ }^{3}$

Este ensaio busca traçar uma breve história da curadoria em arte com foco nas atribuições e no papel social do curador, tendo como ponto de partida sua relação com o museu e a história da arte. Muito embora o uso do termo curadoria para designar uma atividade profissional específica no campo da arte seja relativamente recente, o seu exercício está associado à prática do colecionismo e suas transformações ao longo do tempo. Para abordar esse tema elegemos alguns personagens emblemáticos, situados em uma temporalidade alargada que abarca desde meados do século XVI até o início do século XXI. Estes serão entendidos não como os únicos responsáveis pelas mudanças de paradigma no campo da curadoria, mas como catalisadores de certas práticas e procedimentos, que por seu intermédio passaram por um processo de consolidação, contribuindo, assim, para (re)definir a curadoria diante dos desafios de seu tempo.

As atribuições do curador de arte encontram-se, em parte, predefinidas na origem etimológica do verbo curar. Curar origina-se do latim "curare" que numa acepção primeira diz respeito ao cuidado com alguém ou alguma coisa. A essa dimensão física sobrepõe-se outro sentido, que se remete àquele "[...] que tem por incumbência legal ou judicial, a função de zelar pelos bens e pelos interesses dos que por si não o possam fazer". ${ }^{4}$ Desse ponto de vista o curador também pode ser alguém designado judicialmente para assumir a tutela daqueles considerados incapazes, tanto no caso de apresentarem algum tipo de limitação física ou mental que os impeça de tomar suas próprias decisões, quanto pelo fato de não terem atingido a maioridade. É somente a partir de 1661 que o termo passa a designar também "alguém responsável por um museu, uma biblioteca, um zoológico ou outro lugar de exposição". 5 Tomaremos esses sentidos como ponto de partida de nossas reflexões, considerando que a curadoria de arte,
3. Cf. Balzer (2015).

4. Definição datada do século XV. Cf. Cunha (2012, p. 195).

5. Cf. Fowle (2007, p. 26-35, tradução nossa). 
6. Para usar uma expressão sugerida pelo historiador da arte alemão, Hans Belting, podemos falar na Era da Arte a partir do período. Cf. Belting (1994) (primeira edição em alemão, 1990).

7. Nesse período os artistas da corte eram contratados, frequentemente, não apenas como pintores, mas também para cuidar das coleções reais. Por terem formação artística e conhecimentos específicos sobre pintura e outras técnicas eram chamados para atuar na organização das coleções, assim como na conservação e eventual restauração delas quando necessário. Cf. Warnke (2001).

8. Embora haja precedentes de catálogos de coleções, especialmente de antiguidades, produzidos antes do Theatrum Pictorium, a sua inovação consistiu em destacar a dimensão visual das obras por meio de reproduções. Cf. Waterfield (2006, p. 41-57). enquanto prática social, é historicamente determinada, ou seja, transforma-se ao longo do tempo, sendo constantemente ressignificada.

\section{ANTECEDENTES: COLECIONISMO E CURADORIA}

O colecionismo e a preservação de objetos entendidos como artísticos são práticas milenares, que podem ser observadas desde os antigos gregos, entre os quais situa-se um primeiro debate sobre a natureza da imagem e da pintura. Assim, a prática da curadoria tem uma história de longa duração, que, no caso da arte, ganhou contornos mais precisos na Idade Moderna. A pesquisa historiográfica e museológica situa a formação de coleções de pintura paralelamente à emergência da pintura de cavalete e dos gabinetes de curiosidade, entre os séculos XV e XVI. A pintura de cavalete surge como um novo suporte artístico, transformando a obra em um objeto transportável e, consequentemente, mais facilmente comercializável e colecionável. Nesse momento assistimos à formulação de um discurso sistemático e autônomo sobre a arte, dando origem a uma literatura responsável por engendrar a noção de arte e consolidar o seu processo de autonomização como o conhecemos hoje. ${ }^{b}$

Um dos exemplos emblemáticos deste fenômeno é a coleção de pinturas do Arquiduque Leopoldo Guilherme da Áustria (1614-1662), que como governador dos Países Baixos Espanhóis (atual Bélgica) reuniu um conjunto de cerca de 1.400 obras, parte das quais iria compor o núcleo inicial do acervo do Museu de História da Arte de Viena, dois séculos mais tarde. Em 1650, Leopoldo Guilherme empregou o pintor flamengo David Teniers, o Jovem 11610 1690), não só para auxiliá-lo na aquisição de obras, mas também para administrar sua coleção. ${ }^{7} \bigcirc$ pintor foi responsável por organizar o que ele chamou de Theatrum Pictorium, publicado em 1660, em quatro idiomas. Nele, inventariou 243 obras da coleção de pinturas italianas, com os nomes dos artistas, os títulos das obras, dados precisos de suas dimensões, reproduções em miniatura de cada uma delas, além de gravuras de representação da disposição da coleção do arquiduque em seu palácio, criando assim um dos primeiros modelos bem-sucedidos de catálogo geral de uma coleção de arte. ${ }^{8}$

Teniers encarregou-se, ainda, de imortalizar a coleção em uma série de dez pinturas em que retrata os aposentos do palácio real com as paredes cobertas de quadros e a presença de visitantes, além do arquiduque e de si mesmo, em 
diversas situações. ${ }^{9}$ Até então esse tipo de representação era raro, mas logo se tornaria um gênero de grande sucesso, especialmente na região da Antuérpia, sendo designado como pintura de gabinete. ${ }^{10}$ A distribuição das pinturas, justapostas na parede de alto a baixo, formando uma espécie de mosaico, tornou-se característica desse tipo de coleção, sendo adotada pelos salões de belas artes até a segunda metade do século XIX. Tal arranjo valorizava a simetria, tinha um forte componente decorativo que se somava à rica ornamentação dos palácios e, em grande medida, aproximava-se do modo como eram apresentados os objetos nos gabinetes de curiosidades. " "Na figura de David Teniers vemos, portanto, alguns dos primeiros indícios do trabalho de curadoria de arte, tendo as suas ações se tornado paradigmáticas para o tratamento de coleções de pintura até pelo menos a criação dos museus de arte no século XIX.

Em relação ao Brasil, é preciso assinalar que o fato de o país ter sido um território colonizado durante três séculos o situa numa posição peculiar na história da curadoria, da arte e dos museus. A sua história começa a ser narrada a partir da declaração de seu território como colônia europeia. Isso significa que suas culturas visuais autóctones foram transmitidas segundo preceitos e valores europeus, alheios aos desejos ou interesses locais e submetidas a um jugo cultural que estende seu impacto até os dias atuais. $\bigcirc$ Brasil, portanto, "nasce" concomitantemente ao colecionismo moderno, ou seja, à formação dos gabinetes de curiosidades e coleções de pinturas nos países europeus e, não por acaso, viria a ser um dos muitos lugares dos quais grandes quantidades de objetos e artefatos foram levados para compor coleções europeias. No entanto, não há, na literatura especializada brasileira, nenhum estudo que tenha atentado para a possível emergência de uma prática curatorial em território brasileiro no período. ${ }^{12}$

Acreditamos ser possível interpretar a formação da coleção do conde João Maurício de Nassau como o momento inaugural do colecionismo moderno no Brasil. Governador do Brasil holandês, instalado na capitania de Pernambuco entre 1637 e 1644, Nassau empenhou-se em reunir elementos da flora e da fauna, além de minerais e artefatos produzidos pelas populações locais. A sua coleção seguiu um projeto baseado nos princípios vigentes para a formação de gabinetes de curiosidades e gabinetes de pintura na Europa. ${ }^{13}$ Podemos identificar uma dimensão curatorial no mecenato de Nassau a artistas e naturalistas que trouxe ao país. Os pintores holandeses Albert Eckhout e Frans Post foram designados para produzir representações o mais fidedignas possíveis da realidade local. Enquanto o primeiro recebeu a incumbência de pintar retratos dos habitantes da colônia, ao segundo foi dada a missão de registrar a paisagem. A coleção de Nassau seguiu com ele em seu retorno a Haia e foi dispersada paulatinamente nos anos seguintes por meio
9. Essas pinturas visavam difundir a coleção do Arquiduque e aumentar o seu prestígio junto a outras cortes importantes da Europa. Há divergências sobre o número de pinturas realizadas por Teniers. Adotamos como fonte a listagem produzida por Van Claerbergen (2006, p. 15,65$)$. Para uma análise mais completa da vida e da obra de Teniers e seu engajamento com a formação da coleção do Arquiduque Leopoldo Guilherme, veja-se Haag (2014).

10. Van Claerbergen (op. cit., p. 68).

11. Cf. McClellan (2008, p. 120-132). Esse padrão expositivo seria mantido em diversas localidades até o século 20. Sobre essa permanência nas exposições realizadas no Brasil ver: Nascimento (2010); Valle (2011).

12. A maioria dos estudos sobre a história da curadoria de arte no Brasil foca a curadoria de arte na segunda metade do século 20. As pontuações sobre o caso brasileiro ao longo deste texto visam pensar como a prática curatorial teve papel fundamental na narrativa do território, que necessariamente passava pelo colecionismo de objetos e pela produção da imagem do Brasil, enquanto colônia moderna, através da pintura e da gravura.

13. Cf. Françozo (2014). 
14. Cf. Bennett (1995).

15. O Museu Napoleão (1802-1815) teve origem na transformação do Museu Central das Artes e da República, criado em 6 de maio de 1791 por decreto da Assembleia Nacional da França durante o período revolucionário, que foi reorientado para a reunião de objetos artísticos produzidos, e outros tantos depois saqueados, por Napoleão Bonaparte durante seu reinado. Vivant-Denon foi designado como diretor das artes do Império Napoleônico, nomeado pelo próprio imperador para assumir a direção do museu, onde atuou até a queda de Napoleão, em 1815. A partir do período da Restauração, o museu é renomeado como Museu Real do Louvre e inaugurado em 22 de julho de 1816. Para uma análise crítica da vida e da obra de Vivant-Denon, veja-se: $<$ https://bit.ly/2QC1Nzn>. de presentes dados por ele próprio a membros da alta nobreza europeia, de acordo com seus interesses políticos e diplomáticos.

\section{O SURGIMENTO DOS MUSEUS PÚBLICOS E A PROFISSIONALIZAÇÃO DA CURADORIA}

O surgimento dos museus públicos no final do século XVIII ocorreu como resultado de um processo de transformação social ligado aos ideais iluministas, à política mercantilista dos Estados e à ascensão da burguesia. Muda-se do particularismo aristocrático, que considerava a existência de pessoas naturalmente diferentes, com mais méritos e mais direitos do que outras, para o universalismo burguês, que concebe todos os indivíduos como iguais. Isso implicou uma ampla transformação que resultou, entre outras coisas, na reivindicação de acesso público às coleções. Assim, a burguesia procurou organizar o campo do saber e do conhecimento para consolidar o seu poder, sendo o museu colocado a serviço dessa tarefa. Pensadores da época passaram a defender a educação como a grande arma do Estado moderno, e nesse contexto o museu público assumiu um importante papel. ${ }^{14}$

$\bigcirc$ advento dos museus públicos faria com que a figura do curador deixasse de ser exclusiva da esfera privada e passasse a exercer também atividade institucional no âmbito do Estado. Ao longo do século XIX o trabalho de curadoria de coleções se tornaria cada vez mais especializado, pautando-se pela adoção de métodos e dando origem a uma nova profissão - o conservador de museu - em um processo muito semelhante ao ocorrido em outras áreas. Do ponto de vista técnico, as atribuições do conservador de museu permaneceram basicamente as mesmas do curador das coleções reais e aristocráticas, uma vez que ele continuaria a ser responsável pelas atividades de aquisição de obras, conservação, catalogação e exibição. As diferenças ficariam por conta de sua responsabilidade diante da missão educativa e civilizadora do museu, voltado a partir de então para um público em expansão cada vez mais diversificado.

O tipo de trabalho desenvolvido por David Teniers, em que o artista assumia as funções de conservador, documentalista e encarregado pela aquisição de obras junto a uma coleção específica, reverberou mais tarde no papel assumido pelo pintor, gravador, desenhista e colecionador, Dominique Vivant-Denon (1747-1825). Nomeado, em 1802, por Napoleão Bonaparte como diretor do Museu Napoleão, que alguns anos depois daria origem ao Museu do Louvre, ${ }^{15}$ Vivant-Denon acrescentou ainda outras atribuições à prática curatorial. Como crítico diletante dos 
salões da Academia de Belas Artes de Paris, ele assistiu ao surgimento das teorias estéticas do período, bem como à disseminação de escritos tratando da narrativa da arte para além da biografia dos artistas, ${ }^{16}$ não tendo se furtado de escrever sobre as coleções pelas quais tornou-se responsável. Dentre as novas atribuições assumidas por Dominique Vivant-Denon estava a seleção dos butins das bemsucedidas campanhas bélicas napoleônicas. Ele frequentemente viajava com o exército francês para orientar a pilhagem de bens de interesse artístico e cultural nos países conquistados. ${ }^{17}$ Essas expropriações eram consideradas legítimas, pois, sendo a França o berço dos ideais iluministas, supostamente caberia a ela a formação e preservação de um patrimônio cultural universal para a Humanidade.

Vivant-Denon investiria ainda na implementação de novos modos de dispor as pinturas nas paredes do Museu do Louvre. Assim, instalou a Galeria Rafael segundo critérios que visavam oferecer a oportunidade de aprendizado para o público, isto é, de maneira simétrica e cronológica, por escolas e artistas, oferecendo uma visão comparativa da obra dos grandes pintores em relação a seus contemporâneos, em especial à produção de mestres e discípulos. ${ }^{18}$ Essa opção seguia a tendência à racionalização dos modos de expor que ganhou força ao longo do século XIX, baseada em critérios objetivos da história da arte e não mais na tradição dos gabinetes de pintura ou no gosto dos proprietários das coleções. ${ }^{19}$

A atividade curatorial exercida por Dominique Vivant-Denon é definidora do novo papel exercido pelo conservador do museu de arte ao longo do processo de profissionalização e especialização dos museus durante o século XIX. $\bigcirc$ próprio Museu do Louvre, a National Gallery de Londres (fundada em 1824), o Museu de História da Arte de Viena (aberto ao público em 18911) o Metropolitan Museum de Nova York (1870) e, em geral, os museus nacionais de belas-artes no continente americano passaram a contar com um corpo de conservadores, ${ }^{20}$ trabalhando com coleções específicas, em grande medida definidas a partir de periodizações sistemáticas da História da Arte e das escolas de pintura consagradas. Esses acervos costumavam ser apresentados em sua totalidade, em caráter permanente, sendo os profissionais especialistas responsáveis pela aquisição, conservação e documentação das obras, bem como por seu arranjo no espaço expositivo. Naquele momento, os acervos eram entendidos como possuidores de valores universais imutáveis. A prática de serem reinterpretados, por meio da renovação periódica dos arranjos das obras em exibição, somente mais tarde seria adotada pelos museus.

No caso do Brasil, o início do século XIX é marcado pela chegada da Colônia Lebreton, ${ }^{21}$ em 1816, no contexto do estabelecimento da corte portuguesa no Brasil, que deu origem à Academia Imperial de Belas Artes. Nela, identifica-se
16. Além dos escritos de Luigi Lanzi (Storia pittorica della Italia,1795-96), assinalamos o famoso Geschichte der Kunst des Alterthums, de 1765, que Johann Joachim Winckelmann publicou como bibliotecário e curador das coleções papais em Roma.

17. Cf. Blom (2002).

18. Cf. McClellan (op. cit.). Cabe lembrar que ainda no século XVIII, as coleções imperiais da Áustria foram abertas ao público pela primeira vez, sendo assim arranjadas no Palácio do Belvedere. $\mathrm{O}$ artista da corte imperial dos Habsburgo Christian von Mechel teria sido o pioneiro no modo de disposição das obras de uma coleção de pinturas, ordenando-as por escolas de pintura, ainda em 1781. Cf. Husslein-Arco; Schoeller (2011).

19. O termo "gabinete" com suas qualificações específicas (neste caso, "de pintura”) emerge na primeira era do colecionismo da nobreza e das monarquias da Europa, quando as coleções da Era Moderna se formaram e começaram a se especializar. Em um primeiro momento, e na acepção do gabinete de curiosidades, objetos das mais diversas proveniências e tipologias eram dispostos segundo critérios de correspondência, de modo a constituir um Theatrum Mundi, ou seja, essas coleções "organizadas pelos príncipes e senhores renascentistas, funcionavam como paradigmas visuais que recriavam simbolicamente a ordem do mundo e o espaço do exercício de seu poder". Esses gabinetes ou Wunderkammern (literalmente, "câmara das maravilhas" em alemão) se especializaram depois em gabinetes apenas de pinturas ou objetos de arte, e outras tipologias de objetos, mas ainda operando 
segundo a premissa das correspondências entre os objetos apresentados, que podiam ser de ordem formal, de proveniência, de técnica ou de acordo com o gosto de seus proprietários. Cf. Meneses (1994). Ver também: Hooper-Greenhill (1992).

20. Este é o termo mais usual quando se fala de um especialista trabalhando em um museu de arte até meados do século XX. Ainda hoje, em um país como a França, o termo "conservador" é usado para designar o especialista que trabalha com segmentos específicos dos acervos artísticos nos museus de arte. Veja-se, por exemplo, o organograma do Museu do Louvre, no qual seus nove departamentos curatoriais estão agrupados como Départements de Conservation et du Musée National Eugène Delacroix [Departamentos de Conservação e do Museu Nacional Eugène Delacroix]. Disponível em: <https://bit.ly/39dMqU3>. Acesso em: 23 maio 2019. Observe-se ainda que no caso francês, a formação de um conservateur na Escola do Louvre envolve conhecimentos de história da arte e de princípios de conservação e restauro, e de documentação de acervos.

21. Por muitas décadas referida na historiografia da arte no Brasil como "Missão artística francesa”, sua atual denominação reflete pesquisas recentes, realizadas entre o Brasil e Portugal, que deixaram claro que não se tratava propriamente de uma missão artística, uma vez que D. João VI, rei de Portugal, não convidou Lebreton e seus discípulos para se estabelecerem no Brasil, mas que foi o grupo de artistas franceses quem negociou com diplomatas portugueses sua vinda ao Brasil. Cf. Telles (2017, p. 15-39) e Squeff (2005). um propósito curatorial nos projetos de artistas como Manoel Araúio Porto Alegre e Pedro Américo, a exemplo dos modelos europeus do século XIX. Araújo Porto Alegre, além de ter sido o primeiro artista a ocupar a cátedra de História da Arte na Academia, esteve envolvido com outros projetos de trato e articulação de coleções de pintura. Pintor, professor e crítico de arte, Araújo Porto Alegre é apontado pela pesquisa mais recente como personagem central, não só na estruturação do ensino acadêmico, mas também como alguém que contribuiu para as primeiras formulações de uma história da arte brasileira. ${ }^{22}$ É a partir de sua proposição de identificar e criar uma "escola de pintura brasileira" e, consequentemente, uma coleção da escola brasileira, que se inaugurou um colecionismo sistemático de pinturas executadas por artistas acadêmicos brasileiros. ${ }^{23}$ Esse projeto foi levado adiante pelo pintor Pedro Américo de Figueiredo ao propor, como deputado federal da nascente República Brasileira, a criação, por decreto, de uma Galeria Nacional de Belas Artes. ${ }^{24}$

\section{CRÍTICA E CURADORIA}

Na segunda metade do século XIX, a disseminação cada vez mais frequente das exposições temporárias, a emergência do mercado de arte, organizado em torno de marchands e galeristas, bem como a especialização da imprensa, fizeram com que entrasse em cena um novo personagem: o crítico de arte. ${ }^{25}$ Este viria a ser um profissional-chave na defesa da arte moderna e talvez seja por seu intermédio que possamos observar o início da separação entre a História da Arte e a curadoria de arte. A crítica de arte, ao longo do século XIX, esteve mais próxima dos artistas e das obras de arte do que dos processos de documentação e conservação destas últimas nas coleções e museus. Ademais a disciplina de História da Arte dentro das universidades voltou-se, em um primeiro momento, ao estudo da tradição clássica da arte, sem considerar a produção artística contemporânea como objeto de estudo. Por fim, a produção contemporânea colecionada pelos museus de belas-artes do século XIX era a chamada arte acadêmica, que reverenciava a tradição clássica da arte e, ao mesmo tempo, era catalogada e descrita tomando de empréstimo a categorização da arte do passado. A crítica de arte que escreveu sobre essa produção não estava diretamente vinculada aos conservadores dos museus de arte. Ela atuava muito mais no contexło das exposições temporárias do que nas instituições. 
Talvez em consequência da própria retórica iconoclasta das vanguardas artísticas, a conservação de sua produção não fosse propriamente uma questão. Houve uma grande luta para o ingresso da arte moderna nos museus de arte, como no caso exemplar da doação que o pintor Gustave Caillebotte legou em testamento ao Museu do Luxemburgo, ${ }^{26} \mathrm{em}$ Paris. Tratava-se de uma arte que se projetava em direção ao futuro, utilizando-se de materiais industriais novos, em um momento no qual a crença no progresso técnico-científico não tinha precedentes e, por isso mesmo, não previu nem imaginou o seu envelhecimento ou seu possível esquecimento e destruição. De fato, encontramos dentre as palavras de ordem mais radicais desses artistas o ataque aos modos de institucionalização da arte, com o museu de arte sendo questionado quase imediatamente após sua consolidação. ${ }^{27}$

\section{MUSEUS DE ARTE MODERNA E CURADORIA}

Ao longo da primeira metade do século XX, observa-se um processo paulatino de especialização e separação de acervos artísticos, abrigados até então em instituições museológicas de caráter enciclopédico, que resultaria no museu de história da arte, no museu de belas-artes e no museu de arte moderna. ${ }^{28}$ O processo de especialização do museu de arte moderna, em especial, exigiu que seu conservador estivesse mais próximo do exercício da crítica de arte, pois a missão deste novo profissional era inédita e desafiadora. Ao mesmo tempo que devia acompanhar as novas tendências e dar-thes inteligibilidade, continuava comprometido com a escrita da história da arte. $\bigcirc$ modelo de curador, eleito pela historiografia da arte como paradigmático dessa nova tipologia de museu, não por acaso desloca-se para o Novo Mundo. Trata-se do Museu de Arte Moderna de Nova York (MoMA), inaugurado em novembro de 1929 e cujo projeto inicial foi elaborado pelo historiador e crítico de arte Alfred Barr (190219811, que ali atuou como diretor artístico entre 1929 e $1943 .{ }^{29}$

Em meados da década de 1920, Barr era um jovem historiador da arte, tendo sido um dos primeiros professores universitários a ministrar disciplinas de arte moderna no país. Formado em Harvard, foi aluno destacado de Paul Sachs, considerado o fundador da museologia moderna nos Estados Unidos. Barr propôs a estruturação do MoMA em departamentos independentes organizados por mídias e, para tanto, tomou como referências o curso que ministrava sobre arte moderna e os modelos da Vkhutemas e da Bauhaus, escolas de vanguarda russa e alemã, respectivamente, que havia visitado entre
22. Cf. Squeff (2004) e Zanini (2013).

23. Cf. Squeff (2012).

24. O projeto foi levado ao Congresso Nacional em 1895, mas não se concretizou. O Brasil vai ver a criação de seu Museu Nacional de Belas Artes (MNBA) já no século XX, em 1937 , no quadro da política cultural do ministro Gustavo Capanema, na emergência do Estado Novo e dentro da comissão de criação do Serviço de Patrimônio Histórico Artístico Nacional (SPHAN). O documento-base utilizado para a criação do MNBA foi o projeto apresentado por Pedro Américo. Veja-se documentos localizados pela pesquisa de mestrado de Claudia Regina Alves da Rocha (2014).

25. A exposição temporária tem origem nos Salões da Academia de Belas-Artes de Paris, ainda no século XVIII, e se expande no início do século XIX. Cf. Haskell (2000).

26. Cf. Gleis (2019).

27. A exemplo de um dos ditames do famoso "Manifesto Futurista", do poeta Filippo Tommaso Marinetti, publicado no jornal Le Figaro, em Paris, em 20 de fevereiro de 1909 , que associa os museus a cemitérios. Cf. Chipp (1999, p.290-292).

28. Fazemos uma distinção entre o museu de história da arte e o museu de belas-artes, porque no caso europeu e, sobretudo, tomando como pressuposto o modelo francês (paradigmático para a historiografia da arte e da museologia de arte), o primeiro era detentor de acervos de artistas da grande tradição artística - ou, como se dizia no ambiente parisiense da segunda metade do século XIX, o museu dos 
artistas mortos. Já o segundo, forma-se na sistematização da carreira de artista, sua promoção nas exposições anuais da academia, e caracterizou-se como o museu dos artistas vivos. Essa relação é muito clara entre os acervos do Museu do Louvre e do Museu do Luxemburgo, por exemplo. A figura do conservador-curador sempre esteve mais ligada ao primeiro, isto é, ao museu de história da arte.

29. Cf. Kantor (2002). Assinala-se que Barr inicialmente foi nomeado "director" do Museu. Seu retorno ao quadro profissional do MoMA, em 1947, o nomeou "director of the collections" - literalmente diretor das coleções. O termo "diretor artístico" disseminou-se na década de 1950 e esteve mais ligado à organização de exposições de tipo Bienal. Aparece como uma designação, por exemplo, para o profissional que cumpria o papel de curadoria no Museu de Arte Moderna de São Paulo (MAM).

30. Cf. Kantor (op. cit., p. 146-189). A Vkhutemas (1920-1930) e a Bauhaus (1919-1933) tinham como proposta a articulação entre arte e indústria e foram determinantes para a noção de design que temos hoje. Ambas ministravam cursos de pintura, escultura e arquitetura, mas também artes gráficas, design industrial, têxteis, estamparia, cerâmica, marcenaria e metal. Elas transformaram o ensino da arte e visavam formar um novo tipo de profissional adequado à sociedade moderna industrial. Cf. Jallageas; Lima (2018) e Osten; Watson (2019). Sobre a Vkhutemas ver também: Miguel (2006) e Droste (2006).

31. O Museu de Luxemburgo, mencionado anteriormente, foi o primeiro museu dedicado à arte do seu
1927-1928. ${ }^{30}$ Previstos inicialmente em número de seis, os departamentos do MoMA foram implantados paulatinamente. $O$ primeiro foi o de pintura e escultura, ao qual seriam acrescidos os de arquitetura e design, filme, fotografia e desenho, além de um departamento para gravura e livros ilustrados.

Embora naquele período diversos museus possuíssem obras de arte de vanguarda em seus acervos, especialmente na Alemanha, o MoMA foi o primeiro a assumir integralmente a tipologia de museu de arte moderna, como fez anunciar em seu próprio nome. ${ }^{31} \bigcirc$ museu iniciou suas atividades sem possuir acervo, contando com o empréstimo de obras para a realização de exposições temporárias. Foi a coleção de impressionistas e pós-impressionistas de uma das patronasfundadoras do Museu, Lillie Bliss, doada ao museu em 1933, que veio a constituir o núcleo original de seu acervo. $\bigcirc$ recebimento dessa doação acirrou o debate sobre qual deveria ser a natureza do acervo de uma instituição dedicada à arte moderna. ${ }^{32}$ Segundo proposta inicial de seus fundadores, o MoMA deveria constituir um acervo não permanente, que pudesse ser renovado periodicamente quando suas obras deixassem de ser consideradas modernas. ${ }^{33}$ Para isso previu-se um acordo com o Metropolitan Museum, que seria o depositário final das obras rejeitadas segundo tal critério. ${ }^{34} \mathrm{~A}$ subjetividade inerente à avaliação do caráter moderno das obras e a insegurança gerada em potenciais apoiadores do museu quanto ao destino do acervo foram alguns dos fatores que inviabilizaram a proposta. A partir de então, o MoMA assumiria a missão de apresentar ao público, por meio de um núcleo de obras consideradas exemplares, as origens da arte moderna, sua história e seus desdobramentos. Colocou-se em prática o projeto de Alfred Barr, datado de 1933, no qual ele previa uma coleção permanente, idealizada na forma de um diagrama-torpedo, que começava em 1875 e que seguiria adiante, em movimento contínuo através do tempo. ${ }^{35}$

Barr investiv, ainda, na renovação dos modos de expor. Os exemplos de alguns dos museus que visitou, especialmente na Rússia e Alemanha, contribuíram para que adotasse a distribuição das obras em linha reta, na altura dos olhos, com espaçamentos regulares entre si. Buscava, assim, valorizar as obras como fenômeno estético e não mais como resultado de processos históricos ou desenvolvimentos estilísticos. As obras passam a ser fixadas em paredes claras sem ornamentos. Com a colaboração dos arquitetos modernistas essa busca pela neutralidade dos espaços expositivos consolidaria o "cubo branco", conceito cunhado pelo artista e teórico Brian $\mathrm{O}^{\prime}$ Doherty. ${ }^{36}$ Mais do que um local de paredes brancas sem janelas ou conexões com o mundo exterior, o cubo branco é a materialização do espaço ideal da arte moderna, ordenado, racional e pretensamente neutro, capaz de ressaltar a autonomia do objeto artístico e suas características intrínsecas. 
Se o desafio geral de Alfred Barr estava em rever o papel do curador diante dos impasses que a arte vinha colocando desde o final do século XIX, o seu embate cotidiano era tentar compatibilizar a realização de um trabalho curatorial, baseado em princípios de excelência acadêmica e museológica, com os interesses de um museu organizado segundo uma mentalidade empresarial. Essa tendência intensificou-se com a chegada de Nelson Rockefeller à presidência do museu, em 1939, o que acabou por inviabilizar sua permanência no cargo de diretor artístico, do qual se desligou em 1943. De qualquer forma, sua atuação no MoMA criou parâmetros para inúmeras atividades desempenhadas pelos museus de arte moderna a partir de então, tanto nos Estados Unidos quanto no exterior. Veremos a seguir como o seu entendimento da arte moderna repercutiu no Brasil.

advento do modernismo no Brasil ampliou de maneira significativa o campo da atividade curatorial. É possível identificar na crítica de arte moderna atores que estiveram engajados na formação de coleções, na documentação e pesquisa sobre elas, bem como na formulação de um pensamento que pudesse marcar as distinções da cultura brasileira em relação ao contexto europeu. Tais práticas são claras, em especial, na atividade crítica de Mário de Andrade (1893-1945). Para o escritor e musicólogo paulista, o colecionismo de arte estava intrinsecamente articulado à sua defesa da arte moderna e à constituição da narrativa da arte brasileira. No final da década de 1920, ele empreendeu expedições etnográficas que resultaram em uma coleção de objetos das culturas autóctones do Brasil, que hoje encontra-se no Instituto de Estudos Brasileiro da USP. A mesma instituição abriga, ainda, a coleção de arte que Andrade reuniu ao longo de sua vida. ${ }^{37}$

O colecionismo e a crítica eram indissociáveis para o autor, e por isso mesmo o seu comprometimento com a criação de instituições públicas detentoras de acervos e o fomento à arte moderna podem ser entendidos na chave da prática curatorial. Mário de Andrade esteve engajado com a criação de órgãos importantes de documentação e conservação da cultura visual brasileira, a exemplo do Departamento de Cultura do Município de São Paulo, que dirigiv entre 1935 e 1938. Entre seus colaboradores estava o crítico e escritor Sérgio Milliet (18981966) a quem ele designou para dirigir a Divisão de Bibliotecas. Milliet iria implantar a Seção de Arte na Biblioteca Municipal de São Paulo, em 1943, responsável por reunir a primeira coleção pública de arte moderna do país. Para dirigir a Seção de Arte, Milliet indicou Maria Eugênia Franco (1915-1999), crítica de arte que implantou programas de exposições de caráter didático, visando a formação de público para a arte moderna. ${ }^{38}$

A partir da criação do Museu de Arte Moderna de São Paulo (MAM), em 1948, alguns dos críticos de arte que atuaram como diretores artísticos da próprio tempo. Criado por decreto real em 1818, como uma instituição destinada a abrigar obras de "artistas vivos", recebia obras selecionadas nos salões da Academia por uma comissão designada para este fim. Cf. Bonafoux (2005).

32. Parte das reflexões apresentadas aqui sobre a política de acervo e o modo de apresentação das obras adotado por Alfred Barr no MoMA foram desenvolvidas originalmente em Costa (2008).

33. A base de referência para essa proposta foi o acervo não permanente do Museu de Luxemburgo, de Paris, onde as obras deviam permanecer por dez anos após a morte de seus autores. Cumprido o prazo, avaliava-se, então, se haviam sedimentado as qualidades necessárias para serem transferidas para o Museu do Louvre. Sobre a política de acervo do MoMA em seus primeiros anos ver: Kantor (op. cit., p. 365-377).

34. O acordo deveria envolver também o Whitney Museum que seria encarregado mais diretamente da arte moderna norte-americana. Do mesmo modo que o MoMA, ele destinaria obras de seu acervo para o Metropolitan Museum quando estas deixassem de ser consideradas modernas. Cf. Kantor (op. cit., p. 365-377).

35. Junto a esse núcleo permanente o museu podia incorporar obras passíveis de serem intercambiadas com outras instituições ou vendidas de acordo com suas necessidades. Cf. Kantor (op. cit., p. 365-377).

36. Cf. O'Doherty (2002).

37. Cf. Batista (2004) e Batista; Lima (1998).

38. A contribuição de Maria 
Eugênia Franco como crítica de arte e curadora ainda está por ser avaliada. Ela foi uma das raras mulheres atuantes na área nesse período, seguida mais tarde por Aracy Amaral. Sobre Franco, Cf. Leite (2017). Sobre Aracy Amaral, Cf. Cristiana Santiago Tejo (2017, p. 150-163)

39. Cf. Machado (1947).

40. Cf. Avelar (2014). Sobre Gilda de Mello e Souza, Cf. Miceli; Mattos (2007) e Pontes (2006).

41. Como professor da Escola de Sociologia e Política de São Paulo desde 1934, Milliet conviveu com um grupo de professores dos Estados Unidos para a implantação de uma nova frente de formação em economia - sob influência da chamada Escola de Chicago. Cf. Gonçalves (1992). O diplomata norte-americano, Carlton Sprague Smith, membro do conselho do MoMA, foi a ponte entre Milliet e o ambiente artístico norte-americano.

42. Retomaremos a passagem do acervo do MAM à Universidade de São Paulo quando tratarmos do museu universitário de arte. instituição também se comprometeram com a escrita da história da arte no Brasil. Por um lado, o acúmulo de atividades junto ao museu e às edições da Bienal de São Paulo na primeira década de existência do MAM fez com que esses agentes atuassem como críticos, mas também como conservadores de uma coleção de arte moderna. Por outro, o engajamento em um projeto cultural para a construção de uma identidade brasileira demandou que se envolvessem com ações de salvaguarda do patrimônio artístico do país - dando continuidade a ações empreendidas por Mário de Andrade, por exemplo. Destacam-se aqui as atuações de Lourival Gomes Machado (1917-1967), Sérgio Milliet (1898-1966) e Mário Pedrosa (190019811. Com relação a Gomes Machado, ele assumiu a direção do MAM quando acabara de publicar um panorama da arte no Brasil, ${ }^{39}$ ao mesmo tempo em que ensinava estética e história da arte na Universidade de São Paulo, onde foi responsável por levar adiante o primeiro programa de formação em história da arte na universidade, ao lado de Gilda de Mello e Souza (1919-2005). ${ }^{40}$ Já Sérgio Milliet assumiu a direção artística do MAM e, em seu duplo papel de diretor do museu e diretor artístico da Bienal, foi reconhecido por seus contemporâneos por apresentar o mais importante panorama da arte moderna mundial exibido no país, até então, na II Bienal de São Paulo, inaugurada em dezembro de 1953. Vale lembrar ainda que Milliet havia sido figura-chave nos debates que levaram à formação da primeira comissão de criação do MAM de São Paulo. Além disso, através de suas relações com o ambiente norte-americano, a elite paulista aproximou-se dos representantes do MoMA, em Nova York. ${ }^{41}$

Ao final da década, no contexto que levou à separação entre a Bienal de São Paulo e o MAM, Mário Pedrosa também teve um papel importante em pensar a história da arte no Brasil. Ao acompanhar como diretor artístico do museu a criação da Fundação Bienal de São Paulo e a transferência das coleções do MAM para a USP, entre 1962 e 1963, Pedrosa elaborou um programa de formação em história da arte para o museu que seria inaugurado na universidade, integralmente voltado para o perfil da coleção antes pertencente ao MAM.42 Além do mais, sua atuação junto à Associação Internacional de Críticos de Arte (AICA), do qual foi presidente da seção brasileira, levou-o a acompanhar debates importantes que se instauraram, principalmente nos países europeus, sobre os museus de arte moderna. Sua contribuição, por fim, não se resumiu apenas ao MAM de São Paulo. Em 1978, na condição de conselheiro do MAM do Rio de Janeiro, Pedrosa elaborou a proposta do que ele chamou de Museu das Origens, ainda sob o impacto do incêndio que levou à perda do acervo inicial da instituição carioca. $\bigcirc$ seu projeto de museu, articulado a um acervo de arte moderna, abrigaria outras quatro tipologias de acervo a ele relacionados: um 
museu de arte do inconsciente, um museu de arte indígena, um museu de arte popular (ou virgem) e um museu de arte afro-brasileira. ${ }^{43}$

É preciso assinalar, ainda, a criação do Museu de Arte de São Paulo Assis Chateaubriand (Masp), em 1947, e o modo a partir do qual seu primeiro diretor, - jornalista e crítico italiano Pietro Maria Bardi (1900-1999), concebeu a apresentação de seu acervo permanente e seu programa de exposições temporárias. Apesar de ter uma coleção inicial de arte europeia que dava conta de uma narrativa consolidada pelos grandes museus de arte da tradição no Velho Continente, Bardi deliberadamente evitou qualquer menção no nome do museu a termos que identificassem um recorte temporal. Em sua concepção, embora o museu tivesse um acervo de arte da tradição, esta deveria dialogar com a produção do tempo presente e, mais do que isso, só poderia ser interpretada a partir do tempo presente. ${ }^{44}$ Assim, a apresentação da coleção do Masp em seus primeiros anos de existência era antecedida por uma exposição didática, na qual o visitante era introduzido à história da arte. Ao mesmo tempo, o museu sediou exposições de artistas modernos importantes como no caso de Alexander Calder e Max Bill. Por fim, o MASP criou uma escola de arte, o Instituto de Arte Contemporânea (IAC), por meio do qual introduziu-se no Brasil o debate mais atualizado sobre as relações e colaborações possíveis entre arte e indústria. ${ }^{45}$

- Masp é um estudo de caso fundamental não apenas para a curadoria de arte, mas também para a expografia. A arquiteta italiana Lina Bo Bardi (1914-1992), orientada pelo programa museológico delineado por Bardi, propôs uma expografia moderna, não hierarquizada, para a apresentação das coleções do museu. Já na sua primeira sede no edifício dos Diários Associados, o Masp fez uso de painéis e suportes modulares e móveis. Essas primeiras experiências consolidaram-se no projeto para a sede definitiva do museu, inaugurada em 1968. Lina criou um espaço integrado e transparente para a pinacoteca, em que cada obra era instalada em um painel de vidro ou "cavalete de vidro", segundo a designação dada por ela. ${ }^{46}$ Esse modo de "display" do acervo do Masp conferia uma sensação de flutuação das obras e coadunava-se com a ideia de desconstruir as hierarquias cristalizadas na apresentação das obras característica dos museus de arte tradicionais.
43. Sobre a trajetória intelectual de Mário Pedrosa, Cf. Arantes (2004). Sobre o novo projeto para o MAM do Rio de Janeiro após o incêndio, veja-se Mário Pedrosa (1978).

44. O projeto de museu de arte de Bardi ainda está por ser devidamente estudado. Destacam-se como fontes importantes seus artigos de divulgação do Masp na revista Habitat (1951) e no ambiente europeu no início da década de 1950, somados aos catálogos por ele organizados quando da itinerância das obras que adquiriu para o museu pelas capitais europeias entre 1953 e 1957. Tal projeto encontra-se também em Bardi (1956).

45. Sobre o Instituto de Arte Contemporânea do MASP, veja-se Leon (2013). Ver também: Leon (2014).

46. Sobre a retomada dos cavaletes de vidro da pinacoteca do MASP, em 2015, veja-se Pedrosa e Proença (2015). No discurso atual da instituição, as expografias propostas por Bo Bardi para o MASP (desde sua sede na Rua Sete de Abril) têm sido trabalhadas como parte inerente do acervo. 
48. Cf. O'Neil (2012, p. 9-50).

\section{CONSERVADOR DE MUSEU VERSUS CURADOR INDEPENDENTE}

Como vimos, a crítica de arte modernista foi fundamental não apenas para o estabelecimento de chaves interpretativas para a arte da primeira metade do século XX, como também para a sua institucionalização. O museu moderno pautouse pelo discurso da autonomia da obra de arte para a formação de seus acervos, bem como para a inteligibilidade, documentação e exibição das obras. A ideia de autonomia da obra de arte levou à categorização estanque de pinturas, esculturas, desenhos, gravuras e fotografias, que passaram a ser valorizados por suas características intrínsecas, apartados dos contextos históricos em que foram produzidos. A passagem do sistema de arte moderna para o sistema de arte contemporânea iria modificar radicalmente essas premissas. Como aponta Anne Cauquelin, a arte abandona o campo da estética para inserir-se na esfera artística e já não é mais possível encontrar sentido na obra de arte em si. ${ }^{47}$ Assim, o artista contemporâneo promove a diluição das fronteiras entre arte e vida, explora as potencialidades do múltiplo, adota estratégias de apropriação e, frequentemente, abraça a efemeridade ao produzir objetos precários ou realizar ações artísticas. Além disso, deixa de privilegiar o museu como destino inevitável de sua produção e passa a transitar em espaços não institucionais ou a interferir diretamente no tecido urbano. Uma transformação de tal amplitude iria causar forte impacto no papel do conservador de museu e do próprio museu, agentes que, até então, eram protagonistas no processo de conferir inteligibilidade e valoração à obra de arte.

Nesse contexto surge o chamado curador independente, ${ }^{48}$ que diante da radicalidade das mudanças em curso no sistema de arte busca reinventar a atividade curatorial, para além das atribuições tradicionais do conservador de museu. Não se trata mais do especialista no trato de coleções, do historiador ou do crítico de arte, mas de alguém movido por interesses multidisciplinares que se coloca como um agente cultural capaz não só de viabilizar o trabalho do artista, mas também potencializá-lo por meio do acompanhamento direto do processo de criação e obtenção de recursos financeiros para a execução das obras. Liberto das demandas tradicionais das instituições museológicas, o chamado curador independente irá desafiar as fronteiras entre curadoria, crítica e atividade artística, encarnando frequentemente o papel de criador e abrindo possibilidades experimentais no âmbito da curadoria, até então impensáveis em se tratando do ambiente tradicional das instituições museológicas.

Ao assumir tal protagonismo, o curador independente não raro é acusado de utilizar as obras dos artistas como ilustração de seus enunciados. De fato, muitas 
vezes as obras passam a ser produzidas em torno de um conceito estabelecido pelo curador segundo uma narrativa pessoal, e são projetadas para um determinado contexto expositivo, tornando-se dele indissociável. A independência desse novo curador diz respeito à sua atuação como profissional freelancer, sem vínculo institucional ou compromisso com uma dada coleção. Na maioria dos casos, no entanto, a sua autoproclamada independência é relativa, especialmente quando se leva em consideração os seus vínculos com o mercado de arte contemporânea e o fato de que exerce suas atividades em meio a uma rede de relações de poder nem sempre explícitas, mas determinantes para o exercício de suas funções.

É justamente na emergência de mais uma nova tipologia de museu, o museu de arte contemporânea, que se fará a separação mais evidente entre as práticas de documentação e conservação da arte e a atividade curatorial. Ainda que o debate sobre a arte contemporânea tenha se dado também dentro de um organismo como o Comitê Internacional de Museus (ICOM), na década de 1960,49 o modelo vigente de curador de arte, pela primeira vez, está fora do museu e refere-se a alguém que constrói sua carreira como um "fazedor de exposições". A expressão aparece em depoimentos do curador suíço Harald Szeemann (1933-2005), que a partir da exposição "When Attitudes Become Form", no Kunsthalle de Berna, na Suíça, em 1969, tornou-se um curador nos moldes do que estamos familiarizados atualmente. ${ }^{50}$ Em sua investigação sobre o curador independente, David Levi Strauss levantou outros termos mencionados em entrevistas com profissionais da área, que descrevem atividades muito diferentes das que vimos até agora, tais como: administradores, defensores, autores, bricoleurs, agentes, burocratas, cartógrafos, catalisadores, colaboradores, empresários culturais, nômades culturais e diplomatas. ${ }^{51}$

Certamente, muitos daqueles que assumiram atividades curatoriais junto a coleções e museus, desde David Teniers, foram administradores, autores e diplomatas. No entanto, é significativo que a palavra "historiador" e a palavra "conservador" não estejam presentes nesta listagem. No lugar delas, aparecem termos como advocates ("defensores"), agentes (em inglês, broker, como os que atuam na bolsa de valores) e bricoleurs. A fim de aprofundarmos essa discussão iremos nos deter nos termos "defensores" e "bricoleurs".

○ termo "defensor" é pertinente também à crítica de arte moderna, isto é, à prática daqueles autores que usaram suas palavras para fazer a defesa deste ou daquele grupo de artistas, ou da obra de um artista. ${ }^{52} \mathrm{Na}$ curadoria de arte moderna, assim como na prática curatorial contemporânea, há sem dúvida dois aspectos que se vinculam a essa ideia. $\bigcirc$ primeiro deles é o fato de o curador estar ainda mais próximo dos artistas, a tal ponto que hoje ele(a) é o comissionador de obras novas para exposições temporárias, bem como o agenciador da realização
49. Para tanto, veja os debates que tiveram lugar tanto no congresso internacional da AICA, em 1964 quanto do ICOM. Cf. Zanini (1964, p. 40), no qual o autor resenha os debates de um colóquio especial sobre museus de arte, organizado pelo ICOM-França no momento.

50. Sobre Szeemann, veja-se Phillips; Kaiser (2018). A exposição resultou da sistematização do fundo arquivístico de Szeemann, adquirido pelo Getty Research Institute, em 2011, e seu percurso foi organizado cronologicamente em torno das exposições curadas por Szeemann, apresentando sua documentação para cada caso. Parece-nos importante assinalar que nenhuma delas, ou quase nenhuma, foi propriamente realizada em um museu de arte. Mesmo assim, a exposição dedicada ao seu arquivo e à sua carreira usou o termo "museu".

51. Cf. Strauss (2007, p. 18).

52. Nos termos de Tadeu Chiarelli, a "crítica militante”. Cf. Chiarelli (1995). Alguns exemplos importantes, desde a emergência da pintura impressionista: Émile Zola e sua defesa de Édouard Manet, ou Guillaume Apollinaire na defesa da pintura cubista. 
53. Chamamos de mostras sazonais exposições de arte contemporânea que tomam por modelo a Bienal de Arte e cuja periodicidade é regular. As mais relevantes são a Bienal de Veneza, a Documenta de Kassel (que acontece a cada cinco anos) e a Bienal de São Paulo. A virada do século XX para o século XXI marcou um boom sem precedentes desse tipo de exposição. Cf. Filipovic; Hal; Øvstebø (2010). Elas constituem hoje centros de documentação fundamentais para o estudo da história da arte contemporânea. de projetos artísticos. Isso fica cada vez mais evidente no universo das mostras sazonais, que também se tornaram instâncias relevantes para a difusão da arte contemporânea. ${ }^{53}$ Neste sentido, o curador é muito mais um facilitador de produção de obras do que um cuidador. Com relação ao segundo aspecto da atividade do "defensor", a prática curatorial passa a ser entendida como uma atividade crítica, ou seja, não se trata mais de narrar a evolução da arte, mas de articulá-la a questões contemporâneas, de modo a atualizar também a história da arte.

Ocorre, assim, uma grande ruptura com o que se propunha a ser a curadoria de arte até, pelo menos, o início do século XX, quando os acervos de museus de arte eram abordados segundo uma perspectiva linear e evolucionista da história da arte, numa visada enciclopédica e universalizante. Atualmente, a prática curatorial independente instigou os museus de arte a repensarem o trabalho com acervos artísticos, que agora demandam a reavaliação à luz da compreensão da história do próprio do museu, ele mesmo tomado como objeto de estudo, com seus processos específicos. Desde a emergência das teorias pós-coloniais e a disseminação de práticas decoloniais, a visada crítica dentro do museu de arte tem sido cada vez mais acentuada e procura também responder ou dialogar com questões políticas e sociais do mundo contemporâneo.

O segundo termo, "bricoleur", nos parece ainda mais relevante no modo como a nova prática curatorial vem se estabelecendo. $\bigcirc$ termo vem do francês e designa, de um lado, alguém que vagueia sem rumo, e de outro, aquele que faz toda sorte de pequenos trabalhos manuais sem conhecimento técnico específico. Ou seja, o curador independente dissociou-se da figura do conservador de museu que até então era um profissional com formação especializada, responsável pelas atividades de conservação e documentação de um acervo, ao qual se vinculava, em geral, com dedicação exclusiva. Atualmente há vários percursos possíveis de formação para quem deseja tornar-se um curador. Sua aproximação a disciplinas como a filosofia, a antropologia, a sociologia e, sobretudo, aos estudos visuais e à semiótica pode definir as questões que ele propõe para dar inteligibilidade à produção contemporânea, mas isso não necessariamente significa que ele deva ser diplomado nesta ou naquela área.

Assim, se David Teniers e Dominique Vivant-Denon eram artistas, Alfred Barr historiador e crítico de arte, a nova curadoria de arte contemporânea abriu-se para outros perfis profissionais, como no caso de Harald Szeemann, formado em filosofia. Diante dessa maleabilidade, o que parece garantir a legitimidade do curador independente é seu relacionamento com o sistema da arte - suas redes de sociabilidade com artistas e críticos influentes, com galeristas e colecionadores. 
Do ponto de vista teórico a curadoria de arte contemporânea vem, desde pelo menos a década de 1980, buscando referenciais no campo da filosofia e da antropologia estruturalista, responsáveis por colocar em xeque uma visão universalizante do mundo, e o conceito de arte como próprio de uma cultura eurocêntrica, ou daquilo que podemos chamar de cultura ocidental. ${ }^{54}$ Com essa nova prática, as exposições de arte têm procurado desconstruir hierarquias e categorias estéticas consolidadas. Assim, obras de arte podem ser dispostas junto a documentos e outros objetos que sejam relevantes para o conceito ou tema proposto para uma exposição, e há uma tendência a propor leituras de um acervo artístico a partir de questões extraestéticas ou artísticas em sentido estrito. Nessa nova lógica, parece haver uma condenação das disciplinas ligadas às práticas historiográficas, tomadas como "colonialistas" - a história da arte como exemplo maior dessas disciplinas -, em prol de uma abordagem entendida como de caráter sociológico-antropológico. Na nova perspectiva da atividade curatorial que se firma a partir da década de 1990, a História da Arte saiu de cena. Além de a disciplina ter enfrentado uma crise com o advento dos Estudos Visuais, rapidamente transformou-se em um campo tido como ultrapassado. ${ }^{55}$ Assim, não faz sentido reafirmar escolas de pintura e reconstituir suas histórias, já que o entendimento das obras deslocou-se para outra instância: a de seu diálogo com as questões contemporâneas mais amplas - sejam políticas, econômicas, sociais, filosóficas ou culturais - e com as demandas do público do museu de arte.

No Brasil podemos considerar a atuação do crítico e curador mineiro Frederico Morais como o momento de ruptura com a curadoria moderna. Já em 1962, ele publicou o texto "Revisão do método crítico" em que reivindicava a necessidade de mudança dos critérios de avaliação da arte diante das novas proposições contemporâneas por ele identificadas como vanguardistas. ${ }^{56}$ Morais assume uma posição bastante crítica em relação à mercantilização e institucionalização da arte contemporânea manifesta na organização de eventos, na publicação de textos polêmicos e em suas aparições públicas no circuito de arte. Arte no Aterro foi um projeto em que Moraes montou exposições e coordenou atividades artísticas diversas nos finais de semana do mês de julho de 1968, ao redor do edifício do MAM do Rio de Janeiro. No encerramento do evento, Hélio Oiticica foi convidado a apresentar a ação coletiva Apocalipopótese, na qual mostrou pela primeira vez seus Parangolés, ativados por passistas de uma escola de samba.

Dois anos mais tarde, em 1970, seria a vez de Morais publicar o texto "Contra a arte afluente - o corpo é o motor da obra" em que defendia a necessidade de uma "guerrilha artística", ideia que colocou em prática no evento "O corpo à terra" para o qual foram produzidos os trabalhos Tiradentes: totem
54. Veja-se, por exemplo, a série de exposições organizadas pelo Centre Georges Pompidou, ao longo da década de 1980, na qual filósofos e outros especialistas foram convidados a propor leituras do acervo do $\mathrm{Mu}$ seu Nacional de Arte Moderna da França o que, de certa forma, culmina com a famosa exposição de Jean-Hubert Martin, "Magiciens de la Terre", em 1989. Cf. Steeds; Lafuente (2013).

55. Para uma avaliação desse processo Cf. Nelson; Shiff (1996). Ver ainda: Didi-Huberman (1990). Neste debate, o famoso ensaio de Hans Belting, "The end of the History of Art?", é talvez o início dessa autorreflexão da disciplina. Cf. Belting (1991). A primeira versão do ensaio foi escrita por Belting no momento em que ele assumiu a cátedra de História da Arte, na Universidade de Munique, em 1983. Por fim, a resposta de Arthur Danto aos escritos de Belting. Cf. Danto (1997). Sobre campo dos estudos visuais, veja-se Mitchell (2004).

56. Texto publicado no Estado de Minas em 25 de outubro de 1962. Cf. Tejo (op. cit., p. 150-163). Sobre a trajetória de Morais ver: Oliva (2017). 
57. Cristiana Tejo destaca o pioneirismo de Morais no contexto mundial, tendo em vista que as primeiras experiências do crítico brasileiro aconteceram antes da mostra considerada como marco do surgimento do curador independente, Harald Szeemann, em 1969. A autora atribui esse não reconhecimento ao viés eurocêntrico da historiografia dos estudos curatoriais. Cf. Tejo (op. cit., p. 150).

\section{Fabris (2009).}

59. Cf. Costa (2018); Magalhães (2018).

60. Essa discussão havia sido levantada nos congressos do ICOM e da AICA, no início da década de 1960, acompanhados por Zanini, como dito anteriormente (nota 35). Os termos "museu-templo" (para designar o museu de arte moderna, e seu processo de autonomização e descontextualização) e "museu-fórum" (para designar um museu capaz de aproximar os artistas e seu público, discutir as questões contemporâneas) são emprestados do curador sueco Pontus Hultén, que em 1973 deixou seu país para assumir o grande projeto do Centre National Georges Pompidou, em Paris (inaugurado em 1977). Para o ambiente internacional, o Centre Pompidou é paradigmático da emergência do museu de arte contemporânea.
- monumento ao preso polífico de Cildo Meireles e Situações T/T de Artur Barrio. No primeiro Meireles queimou galinhas vivas amarradas em um poste de madeira, no Palácio das Artes, e no segundo Barrio lançou trouxas de carne e ossos ensanguentadas no Parque Municipal, ambos em Belo Horizonte. Chama a atenção não apenas o ineditismo deste tipo de atitude por parte de um curador no Brasil, mas também a capacidade de Morais de mobilização e viabilização de obras de forte conteúdo político em plena ditadura militar. ${ }^{57}$

Cabe nesse ponto indagar qual passaria a ser o papel do curador de museu a partir do advento da arte contemporânea nas décadas de 1960-1970 e dos desafios que ela impunha às instituições museológicas no Brasil. Walter Zanini, historiador da arte e docente da Faculdade de Filosofia, Letras e Ciências Humanas da USP, tentou responder a essa questão na sua prática curatorial cotidiana. Durante a sua gestão no Museu de Arte Contemporânea da Universidade de São Paulo, entre 1963 e 1978, ele foi capaz de conciliar a missão institucional de tratamento, preservação, pesquisa e exibição do acervo com a exigência de abrigar a produção artística mais radical de sua época. ${ }^{58}$ Parte de seus esforços foram para a aquisição de obras de artistas modernos nacionais e internacionais, para a organização de retrospectivas críticas de nomes proeminentes do modernismo brasileiro, acompanhadas de publicações de referência, bem como para a realização de itinerâncias de pequenas mostras do acervo pelo interior do estado de São Paulo. Quanto à arte contemporânea, Zanini investiu em programas estratégicos de exposições para aproximar jovens artistas do museu, viabilizar a produção artística e angariar obras para o acervo, com ênfase na arte conceitual. ${ }^{59}$ Se retomarmos os termos de uma discussão de época, podemos afirmar que ele soube, em grande medida, articular o que de melhor havia nos modelos do museu templo e do museu fórum. ${ }^{60}$

Mais tarde, após deixar a direção do MAC USP, Zanini atuou ainda como curador de duas edições da Bienal de São Paulo, de 1981 e 1983, para as quais propôs um novo modo de apresentação das obras. Por meio do que ele denominou de apresentação por "analogia de linguagens", Zanini articulou um arranjo das obras sem obedecer aos espaços reservados às diferentes delegações nacionais que participavam da Bienal, abrindo uma nova possibilidade de leitura da produção contemporânea. Vale observar que nessas duas curadorias, ele procurou mapear as novas tendências da produção contemporânea - com destaque para a arte postal -, ao mesmo tempo em que inseriv outras formas de manifestação artística na mostra, como no caso das salas especiais de Arte Incomum e Arte Plumária, na Bienal de 1983. E, nos mesmos anos, Zanini esteve envolvido com um grande projeto editorial sobre a história da arte no Brasil. Os dois volumes de História geral da arte no Brasil, 
publicados em 1983,61 contaram com a colaboração de pesquisadores das universidades brasileiras e com o conhecimento mais atualizado que se tinha naquele momento sobre a história da arte no país. Esses volumes permanecem como o único grande manual na área editado no Brasil.

\section{O CURADOR-AUTOR E A INDÚSTRIA DO ESPETÁCULO}

Ao longo dos anos o curador independente, elevado à condição de curador-autor, ${ }^{62}$ assumiu um protagonismo inédito no sistema de arte e consequentemente grande visibilidade na mídia, o que acabou por ofuscar a atuação, para não dizer a própria existência, do conservador de museu. Este, que antes detinha o poder de construir as narrativas da história da arte a partir de seu lugar privilegiado junto às coleções, passa a ser visto como um funcionário a serviço das instituições, detentor de um saber meramente técnico. ${ }^{63}$ Segundo Heinich e Pollack, ocorre um fenômeno de "desprofissionalização" da curadoria e o reconhecimento da condição de curador-autor passa a ser medido por sua capacidade de estabelecer temáticas multidisciplinares, frequentemente de cunho pessoal, que "atravessam" as obras, pelo desenvolvimento de um certo "estilo" materializado na expografia de suas mostras e pela coerência autoral entre seus diversos trabalhos, de modo a garantir uma boa recepção por parte do público. ${ }^{64}$ Tais condições, segundo Jérôme Glicenstein, ${ }^{65}$ só podem ser cumpridas por um número muito restrito de agentes, sendo o estatuto de curador-autor praticamente inatingível para o conservador de museu e, mesmo assim, restrito a poucos dentre os que atuam no mercado.

A partir do final da década de 1990 o curador independente tende a transformar-se num personagem nômade, atuante no mercado de arte globalizado, que transita em mostras sazonais como as grandes feiras de arte e as inúmeras bienais de arte contemporânea que se multiplicaram nos mais diversos países, bem como nas mostras das galerias corporativas e exposições temporárias de museus de arte relevantes para esse sistema, sendo alguns multinacionais. ${ }^{66}$ Nos casos mais radicais ele se molda à indústria do espetáculo, tornando-se uma espécie de celebridade, que não hesita em associar sua imagem a um estilo de vida pautado na ostentação de um certo status elitizado e no culto a bens de consumo de luxo. Como bem aponta Claire Bishop, esse curador freelancer atua como uma espécie de "corretor de influências" entre os colecionadores, o mercado e as instâncias de financiamento da arte. ${ }^{67}$
61. Cf. Zanini (1983).

62. Heinich; Pollack (1989).

63. David Balzer (2015) atribui um papel passivo ao conservador de museu que teria um contraponto ativo na figura do curador independente.

64. Heinich; Pollack (op. cit).

65. Glicenstein (2012, p. 7172).

66. O'Neil (2012b).

67. Bishop (2015). 
68. Obrist constituiu uma história lendária de sua carreira, ao falar de seu encontro com a dupla de artistas suíços Fischli \& Weiss, aos dezesseis anos, descrevendo-se como um adolescente de origem humilde, filho de um trabalhador, que simplesmente "apareceu" no estúdio da dupla de artistas. Cf. Obrist (2014).

69. Os livros são organizados por países, por temas ou de acordo com a atividade e/ou especialidade do entrevistado. No Brasil, Obrist tem diversos títulos publicados pela editora Cobogó. Sobre o Interview Project, Cf. Ursprung; Obrist (2012).

70. Ibid.

71. Os primeiros estudos em história das exposições datam da década de 1990. Cf. Altshuler (1994); Poinsot (1993); Staniszewski (1999).

72. Veja-se a remontagem de When Attitude Becomes Form. Cf. Celant (2013). Aqui o curador expõe o curador. No Brasil podemos citar a incorporação do arquivo de Walter Zanini ao MAC USP e a realização da exposição Walter Zanini: por um museu público, inaugurada em dezembro de 2013, no MAC USP, sobre a sua trajetória curatorial.

73. O Comitê Internacional de Museus é um órgão do braço cultural das Nações Unidas (ONU), responsável, desde sua criação no imediato segundo pós-guerra, por conduzir políticas para o trato com os bens culturais da humanidade. É responsável pela definição que temos hoje de museu e está organizado em comitês nacionais - dos quais o do Brasil foi um dos primeiros a ser crido. Ao longo dos anos, constituiu também comitês por tipologias de acervo e por atividades museológicas. No caso dos
Neste perfil podemos situar o curador superstar Hans Ulrich Obrist. Nascido em 1968 e de origem suíça assim como Harald Szeemann, Obrist vem construindo a sua imagem como curador no contexto do sistema de arte globalizado. ${ }^{68}$ Paralelamente a suas atividades curatoriais, ele vem se dedicando a um extenso projeto de entrevistas com personalidades de diferentes áreas, entre as quais cientistas, intelectuais, artistas, arquitetos e curadores, dos mais diversos países, que teve início em meados da década de 1980. Por meio de seu Interview Project, Obrist vem acumulando grande quantidade de horas de gravações, que de tempos em tempos são editadas e publicadas na forma de coletâneas em diversos idiomas. ${ }^{69}$ Segundo ele, trata-se de um projeto que se retroalimenta: cada exposição gera novas entrevistas, que por sua vez geram novas exposições. ${ }^{70}$ É como se o próprio curador tomasse para si a tarefa da escrita da história de sua atividade - e por que não dizer da própria história da arte contemporânea - por meio do diálogo com pares e interlocutores por ele escolhidos.

protagonismo conquistado pelo curador independente transformou-o em objeto de interesse acadêmico, como atesta o surgimento e a expansão dos estudos em história das exposições, a partir da década de 1990, bem como a incorporação de arquivos pessoais de curadores a acervos de instituições museológicas. ${ }^{71}$ Esse é o caso de Harald Szeemann, cujos arquivos foram adquiridos pela Getty Foundation, tendo sido ele próprio objeto de uma exposição com foco em sua trajetória curatorial e processo de trabalho. ${ }^{72} \mathrm{Na}$ Bienal de Arquitetura de Veneza, em 2010, parte das gravações em vídeo resultantes do Interview Project, de Hans Ulrich Obrist, transformou-se em objeto de exposição. Outro indicativo da recente valorização da atividade curatorial encontra-se na proliferação de cursos de curadoria, em nível de especialização e pós-graduação lato-sensu, fenômeno global que aponta tanto para uma demanda de mercado, quanto para a atração exercida pela figura do curador independente sobre jovens estudantes, em detrimento muitas vezes do historiador da arte.

\section{MUSEUS UNIVERSITÁRIOS DE ARTE}

Em que pese o fato da criação do ICOM ter se dado em 1946,73 somente em 2000 criou-se um comitê dedicado especificamente a museus e coleções universitários em seu organograma. No entanto, é preciso lembrar que os museus universitários surgiram muito antes da criação dos grandes museus nacionais públicos do século XIX - e do próprio ICOM -, e parecem ter desempenhado um 
papel fundamental em pautar os processos de racionalização de práticas e métodos empregados no tratamento de objetos musealizados. ${ }^{74}$

A origem de coleções e museus universitários remonta às universidades europeias do final do período medieval, com a emergência do que se convencionou designar como "coleção didática" ou de "ensino". As chamadas "coleções de ensino", e depois "museus de ensino", 75 desenvolveram-se a partir da reunião de instrumentos de uso experimental/científico, de coleções botânicas, anatômicas e de exemplares de espécimes, isto é, objetos ligados às ciências da natureza e à emergência da chamada história natural. Elas vieram a ser complementadas por coleções de pesquisadores ligados às universidades, que ao longo de sua carreira reuniram objetos relevantes para sua atividade. Destaca-se aqui a atividade do naturalista italiano Ulisse Aldrovandi (1522-1605), que talvez tenha sido o primeiro pesquisador/colecionador a destinar um conjunto de obras de arte a uma universidade. Ele legou sua coleção de pesquisa à Universidade de Bolonha. Reconhece-se na atividade deste pesquisador uma consciência museológica e, portanto, uma prática curatorial avant la lettre, uma vez que ele dedicou-se à catalogação dos itens de sua coleção, separando-os por tipologia de acervo - daí o recorte claro de um conjunto de obras de arte. ${ }^{76}$

O século XVII verá o surgimento do primeiro museu universitário propriamente dito, o Ashmolean Museum, na Universidade de Oxford, criado em 1683, para o acolhimento da coleção Tradescant de história natural, doada por intermédio do antiquário Elias Ashmole. A principal característica que permite defini-lo como um museu é o fato dele ser uma instituição aberta à visitação pública desde o início, o que the conferiu traços próprios de um museu moderno. ${ }^{77}$ A evolução das atividades e do colecionismo do Ashmolean Museum são importantes para a consolidação da ideia de museu universitário de arte, pois entre a segunda metade do século XIX e as primeiras décadas do século XX, ele deixou de ser um museu de história natural para se transformar em um museu de arte e arqueologia. Seu colecionismo de arte tem início em meados do século XIX, com a aquisição de conjuntos significativos de desenhos de grandes mestres do Renascimento italiano, dentre os quais, Rafael, Michelangelo e Leonardo da Vinci. Além do mais, as coleções de arte do Ashmolean Museum fomentaram o desenvolvimento da disciplina de história da arte na Universidade de Oxford, que estruturou um departamento específico para este campo disciplinar. As relações do Ashmolean Museum com o Departamento de História da Arte da Universidade de Oxford materializaram-se, essencialmente, por meio do estudo das obras de seu acervo nas disciplinas e atividades docentes do departamento. museus de arte, o comitê com maior atuação é o Comitê Internacional de $\mathrm{Mu}$ seus de Arte Moderna (CIMAM). Destacam-se ainda o Comitê Internacional de Documentação em Museus (CIDOC), o Comitê Internacional para a Conservação (ICOM-CC) e o Comitê para a Educação e a Ação Cultural (CECA). Sobre a história do ICOM, veja-se: <https:// bit.ly/3rlQVIN>.

74. Para um resumo da história dos museus universitários e a nomenclatura aqui referida, veja-se Lourenço (2002)

75. Um conjunto de objetos que serviam à formação no campo da pesquisa científica e ao desenvolvimento da ciência.

76. Cf. Haxhiraj (2016).

77. Cf. McGregor (2001). 
78. Cf. Brush (2003).

79. Duncan; McClellan (2018).

80. Os Fogg não tinham nenhuma relação com a Universidade de Harvard, e a decisão da senhora William Hayes Fogg de doar a coleção de arte do casal à universidade previa a criação de um museu de arte na instituição, que, em um momento inicial, não teve papel acadêmico e/ou de formação da coleção. O Museum of Fine Arts de Boston era então o museu que oferecia espaço à formação acadêmica de jovens historiadores da arte para a Universidade. Cf. Orcutt (2006).

81. Cf. Harvard Art Museums (1988).

82. Sobro curso de Barroso veja-se Barroso (1946, 1947). O curso havia sido criado em 1922. Sobre sua criação, veja-se Zen (2015).
Para além do caso britânico, a relação da história da arte como disciplina acadêmica na universidade e a criação de museus universitários de arte tem no Fogg Art Museum, da Universidade de Harvard, nos Estados Unidos, um modelo que parece ter se disseminado para museus não universitários naquele país. Ele também constitui um exemplo emblemático para pensarmos as práticas curatoriais no campo da arte e seu diálogo mais estreito com a museologia e a gestão museal. ${ }^{78}$ Neste sentido, a atuação de Paul Sachs (1878-1965) como docente da Universidade de Harvard foi fundamental. ${ }^{79}$ Ao que tudo indica, sua sensibilidade para as artes visuais e sua carreira pregressa como homem de negócios uniram duas qualidades que teriam revolucionado a vida do museu de Harvard..$^{80} \mathrm{~A}$ partir de 1921, Sachs passaria a ministrar o curso intitulado "Museum Work and Museum Problems", no qual os alunos de história da arte recebiam noções básicas de gestão museológica, conservação e manutenção predial de museus. $\bigcirc$ curso de Sachs formou gerações de diretores e curadores de museus de arte nos Estados Unidos, sendo um de seus mais ilustres alunos ninguém menos do que Alfred Barr.

Podemos dizer que existem dois modelos de relações entre museus de arte e universidade. No caso europeu, a universidade é anterior ao surgimento do museu de ensino e do museu universitário. Particularmente no que diz respeito às coleções de arte, sendo a disciplina de história da arte posterior à formação delas, o mais comum foi a universidade prover seus quadros para estudar obras de arte a eles pertencentes - sendo o Ashmolean Museum uma exceção. Já nos Estados Unidos, os grandes centros universitários perceberam desde o começo a necessidade de criação de "museus-laboratório", nos quais podiam se encontrar historiadores da arte e curadores em formação. ${ }^{81}$ No modelo disseminado pela Universidade de Harvard, por meio do Fogg Art Museum, o historiador da arte é um profissional que atua dentro de um museu de arte, sobretudo como curador de coleções.

No Brasil, a criação de museus de arte e sua relação com a universidade deu-se de modo diferente, embora tenha-se tomado de empréstimo, em alguns casos, os museus europeus como modelo e, em outros, os estadunidenses. primeiro museu a ter um quadro funcional com formação qualificada em museologia foi o Museu Nacional de Belas Artes, no Rio de Janeiro. Seus funcionários foram contratados por concurso público e tiveram entre os selecionados ex-alunos do curso de museus criado por Gustavo Barroso no Museu Histórico Nacional. ${ }^{82}$ Entretanto, esses profissionais haviam tido experiência com coleções de numismática, objetos históricos, entre outras tipologias colecionadas por aquele museu. Embora a instituição também possuísse obras de arte, não havia uma base de história da arte ou experiência no trato com acervos artísticos. Além disso, em um país no qual a formação de universidades só veio a se consolidar no século XX, mais precisamente 
a partir da década de 1930, a relação entre museus e universidade constitui uma experiência relativamente recente. Não há ainda uma historiografia consolidada sobre a formação de museus universitários no país. Neste sentido, a Universidade de São Paulo é talvez o exemplo mais conhecido e mais citado na literatura sobre o tema. Às vésperas da comemoração de seus trinta anos de fundação, no início da década de 1960, a USP projetou um novo campus para suas faculdades e institutos, ao mesmo tempo em que incorporou museus e coleções à sua estrutura. ${ }^{83}$

No que diz respeito especificamente ao MAC USP, é importante destacar que antes disso, houve uma estreita colaboração entre a universidade e o Museu de Arte Moderna de São Paulo (MAM). ${ }^{84}$ A transferência do acervo do MAM para a USP começou em paralelo com os debates sobre o plano-piloto para a construção do novo campus universitário. ${ }^{85}$ Mário Pedrosa, como diretor artístico do museu à época, foi responsável por debater com o comitê de construção do novo campus todo o programa de instauração do MAM na universidade. Seu projeto previa a criação de um curso de história da arte, um curso de formação artística, um curso de desenho industrial e um curso de arte e educação, todos dentro do MAM na USP. ${ }^{86} \bigcirc$ MAC USP iniciou suas atividades na emergência do debate internacional sobre as práticas artísticas contemporâneas, como visto anteriormente. Ao assumir - MAC USP, Walter Zanini, como seu primeiro diretor, procurou documentar e catalogar o acervo. Em seguida, estabeleceu um programa sistemático de aquisições de novas obras por meio de um programa de exposições. Na chave prospectiva, cabe mencionar as exposições Jovem desenho nacional e Jovem gravura nacional (que se alternavam anualmente) ocorridas entre 1964 e 1966, e que deram origem às edições da Jovem arte contemporânea (JAC) que ocorreram entre 1967 e 1974. Através delas e de outras exposições importantes, Zanini também incorporou a fotografia e o vídeo ao acervo do MAC USP. Na chave retrospectiva, a partir de exposições monográficas de artistas modernistas ainda não tratados na história da arte moderna no Brasil, ele incorporou ao acervo outro grupo bastante relevante de obras. ${ }^{87}$

Assim, o MAC USP colocava-se como ponta-de-lança no panorama de museus de arte, alinhando-se com os debates contemporâneos fora do país. Como representante brasileiro do CIMAM e da AICA, Zanini havia participado nos congressos organizados pelas duas associações ao longo dos anos 1960, em que se discutiu justamente a crise do modelo de museu de arte tradicional e a necessidade de transformação da missão dos museus de arte para dar conta dos fenômenos artísticos que estavam surgindo. Portanto, suas ações no MAC USP situam-se entre essas duas concepções de museu, por via de seu programa retrospectivo e seu programa prospectivo. A "virada conceitual" do acervo do MAC USP e as estratégias
83. Cf. Brandão; Costa (2007).

84. Cf. Magalhães (2016).

85. Tendo como ponto de partida a documentação levantada pela tese de doutorado de Renato Maia, sobre projetos arquitetônicos para o MAC USP, a pesquisa do mestrando do Programa Interunidades em Museologia, Gustavo Brognara, está demonstrando o quanto $\mathrm{O}$ projeto inicial do MAC USP era um projeto de acolhimento do MAM enquanto instituição pela universidade. Cf. Maia Neto (2004).

86. Cf. Pedrosa (2003). Originalmente preparado em 1962 e publicado na revista GAM, em 1967. Veja-se também Magalhães (2020).

87. A título de exemplo, veja-se a exposição que Zanini curou de projetos para artes decorativas de Antônio Gomide, em 1968, a partir da qual ele adquiriu 28 projetos de estamparia para tecidos de autoria do artista; ou a exposição retrospectiva da obra de Vicente do Rego Monteiro, que resultou na incorporação de um conjunto de aquarelas que o artista havia produzido no contexto de criação de seu balé marajoara e o livro Légendes, croyances et talismans des Indiens de l'Amazone (1925). 
88. O primeiro programa de pós-graduação em história e crítica da arte foi criado por Zanini, no Departamento de Artes Plásticas da Escola de Comunicação e Artes da USP, em 1980. Já a criação do Comitê Brasileiro de História da Arte (CBHA) se deu em 1972. Cf. <https://bit.ly/3rhye2I >.

89. Observe-se que os cinco curadores considerados exemplares dessa grande narrativa são todos homens brancos oriundos de países como a Holanda, França, Estados Unidos e Suíça. Diante disso, procuramos, mesmo que de maneira sucinta, pontuar experiências curatoriais realizadas no Brasil, que destoam desses modelos por responderem às condições específicas locais, frequentemente de modo crítico e original. empreendidas por Walter Zanini para dar-he uma dimensão de "museu-fórum" devem ser abordadas à luz de exemplos do contexto internacional e da emergência da figura do curador independente na história da arte, especialmente o caso de Harald Szeemann e o debate para a construção do Centre Georges Pompidou. No que diz respeito à noção de curador independente, tal como projetada por Szeemann, há paralelos claros com a atuação profissional de Zanini. A radicalidade das atividades artísticas que ele acolheu no MAC USP, sobretudo a partir do início da década de 1970, correspondia àquela percebida nas escolhas de Szeemann feitas para a famosa mostra de 1969. Deve-se ainda observar que a atividade curatorial de Zanini, no MAC USP, esteve estreitamente ligada aos seus temas de pesquisa como historiador da arte e desenvolveu-se em paralelo ao seu grande empenho na criação de um curso de história da arte para a USP, bem como da seção brasileira do Comitê Internacional de História da Arte $(\mathrm{C} \mid \mathrm{HA})$ - órgão máximo de representação de pesquisadores em história da arte no mundo. Disso resultou, de um lado, a criação do primeiro programa de pós-graduação em história e crítica da arte no país; e de outro, a criação do Comitê Brasileiro de História da Arte (CBHA). ${ }^{88}$

Walter Zanini, portanto, pensou o MAC USP como um "museu-laboratório", não só para a formação dos artistas, mas também para a formação de pesquisadores em artes visuais. Ou seja, a curadoria era, para ele, uma atividade de pesquisa e formação. Aqui, nos aproximamos muito do modelo do Fogg Art Museum de Harvard que, no entanto, desdobra-se em duas frentes muito distintas, se comparado ao MAC USP. No programa inicialmente implantado por Zanini, a história da arte era entendida como um campo disciplinar que deveria enfrentar as práticas contemporâneas - o que, na verdade, só veio a ser assimilado pelos departamentos de história da arte mundo afora duas décadas depois. Já no início do século XXI, a USP implantou um quadro próprio de docentes para seus quatro museus estatutários, incluindo o MAC USP. A carreira docente dos museus estabelecida a partir de 2004 parece revisitar, no caso do MAC USP, a proposta inicial do museu na universidade, isto é, ser um museu que opera como unidade de ensino, pesquisa e extensão.

\section{A CURADORIA DE ARTE PARA ALÉM DO DISCURSO HEGEMÔNICO E ALGUNS DESAFIOS FUTUROS}

Buscamos ao longo desse texto compreender a narrativa hegemônica construída em torno da história da curadoria de arte nos últimos anos, que nos parece ser o ponto de partida necessário para qualquer discussão crítica sobre o tema. ${ }^{89}$ 
Nosso objetivo foi sistematizar e discutir as principais questões que a historiografia da arte vem tratando no campo da curadoria de arte, reunindo paradigmas e estudos de casos que embasaram a história da curadoria tomando por base aqueles que nos pareceram fundamentais para o estudo das práticas curatoriais no Brasil.

Na análise aqui proposta, há dois pontos que merecem ser enfatizados. Como citado anteriormente, há uma tendência em se tratar a curadoria no Brasil apenas a partir da segunda metade do século XX, período que constitui o foco de quase toda a produção bibliográfica em curso. Se considerarmos o passado colonial do Brasil e as características do sistema de arte local, que incluem a fragilidade histórica das instituições museológicas e a profissionalização recente do mercado, já temos um forte motivo para buscarmos analisar a história da curadoria de arte a partir de outros referenciais. Propusemos, assim, uma espécie de história da curadoria "antes da curadoria", ou seja, o reconhecimento de práticas, que, embora não tenham sido nomeadas enquanto tal em sua época, são identificáveis como atividades curatoriais, segundo os parâmetros atuais. Como colônia europeia, o Brasil foi parte integrante de um sistema de colecionismo de artefatos, além de ter sido, ele próprio, objeto de representações que cunharam o conceito de América para o público europeu, o que nos parece uma dimensão fundamental a ser analisada quando se trata de traçar a história da curadoria de arte no país.

O segundo ponto diz respeito à necessidade de recuperarmos contranarrativas que coloquem em xeque a existência de um modelo único de museu, materializado pelo museu de arte ocidental, de vocação patrimonialista e enciclopédica, baseado em uma visão eurocêntrica de mundo. Daí nossa opção em traçar paralelos entre os modelos eurocêntricos/ocidentais e aqueles que selecionamos no caso brasileiro como uma contribuição para pensarmos a história da curadoria de uma perspectiva global. Incluir experiências curatoriais realizadas no Brasil em diferentes momentos históricos, ao longo deste texto, serviu, portanto, ao esforço de identificar contrapontos críticos às práticas curatoriais de arte realizadas no âmbito das instituições tradicionais europeias e estadunidenses, bem como nas grandes bienais, feiras internacionais e galerias do mundo globalizado. Muito embora ainda não tenhamos um volume de pesquisas capazes de dar o devido suporte ao desafio que nos propusemos enfrentar, de maneira ampla, observamos que nos últimos anos surgiram estudos que abriram a perspectiva de entendimento das práticas curatoriais para além da criação das instituições museológicas e da realização de exposições.

O percurso aqui traçado nos permitiu acompanhar uma história de longa duração. Do cuidado com as coleções às exposições temporárias, a curadoria de arte especializou-se e foi responsável por articular discursos de legitimação 
90. O preconceito em relação ao papel do curador de museu continua atual. Segundo Andrew Renton, professor na área de curadoria, no Goldsmiths College da Universidade de Londres: "até recentemente, a maioria dos museus nem creditavam os curadores em suas exposições. Vinte ou trinta anos atrás, curadores eram quase tão poeirentos quanto os objetos poeirentos dos quais eles cuidavam". Não é isso, contudo, que nos mostra o percurso traçado neste texto. Cf. Stoppard (2020).

91. Cf. Sehn (2014).

92. Cf. Magalhães; Beiguelman (2014).

93. Como sugere Andrew McClellan (2008) tornou-se a questão. sobre a arte. Em um primeiro momento, esse discurso constituiu narrativas sobre a arte e os artistas, dando origem à história da arte como disciplina acadêmica. Ao longo do século XX e, sobretudo, diante das experiências de arte moderna, houve um enfoque maior na formação de público, bem como na constituição de quadros profissionais para os museus de arte. A partir da década de 1960, quando a arte, os artistas e as instituições artísticas começam a se consolidar como valores para a sociedade contemporânea, assistimos à partição de uma figura que antes era una: o conservador - ou curador de coleção - e o curador independente. Enquanto o primeiro passa a ser considerado um mero funcionário das instituições museológicas, o segundo ganha protagonismo e, muitas vezes, ares de celebridade, usufruindo do estatuto de autor. Invisibilizar o trabalho curatorial ligado às coleções institucionais e aos museus é negar a longa história que constitui o lastro dessa atividade, enquanto prática social. .90

Nesse contexto, o trabalho de preservação e documentação das coleções públicas já constituídas parece ter se enfraquecido, havendo um foco maior nas ações voltadas ao colecionismo privado. No que tange às grandes coleções corporativas que se formaram ao longo da segunda metade do século XX, a atividade curatorial esteve ligada, principalmente, à aquisição de obras e à promoção dos colecionadores por via de exposições temporárias. Atividades como a conservação e a documentação/catalogação passaram a ser, em geral, terceirizadas e tornaram-se fruto de ações pontuais.

Do ponto de vista da conservação e da documentação da arte contemporânea, ${ }^{91}$ há o novo desafio da preservação digital, isto é, do tratamento de objetos nato-digitais, ou mais amplamente daquilo que, em inglês, convencionou-se chamar time-based media art. Esses objetos, em grande medida híbridos, têm uma história de colecionismo de ao menos duas décadas e têm demandado dos museus estruturas físicas e virtuais específicas, bem como profissionais com novas habilidades. No que concerne ao curador atuante nesta área, ele deve ser capaz de mediar e documentar a proposição artística na sua relação com a instituição, além de imaginar modos de preservação destas, cuja base tecnológica é fadada à rápida obsolescência. ${ }^{92}$

Nesse panorama consideramos importante ressaltar, ainda, que o apelo à democratização do acesso ao público estiveram em discussão desde o surgimento dos primeiros museus. ${ }^{93}$ Hoje esse debate ganhou novos contornos e busca atender à urgência das demandas sociais por instituições museológicas mais inclusivas, abertas ao diálogo e ao acolhimento de diferentes segmentos de público. $\mathrm{Na}$ chave da relação do museu com a sociedade, o debate sobre o respeito às diferenças sociais e culturais, e a necessidade de representar a alteridade, étnica 
ou de gênero, é fundamental. Não por acaso o pensamento decolonial tem sido o eixo condutor da reavaliação dos programas curatoriais de inúmeros museus de arte em função de demandas concretas de grupos organizados. ${ }^{94}$

A título de fechamento podemos afirmar que a curadoria de arte teria, talvez, quatro grandes desafios principais hoje. Primeiro, a preservação das coleções institucionais públicas e seu gerenciamento a partir das novas demandas sociais e das pressões da indústria do entretenimento e do turismo. Segundo, a construção da memória da arte do século XXI diante da efemeridade dos suportes informatizados, que além de implicarem uma obsolescência voraz, demandam novos saberes para sua conservação e documentação. Terceiro, a relação com a produção artística contemporânea, na medida em que o curador tem papel importante na viabilização de proposições artísticas junto às instituições. E quarto, repensar a educação pela arte numa dimensão ampliada.

No momento em que toda e qualquer escolha, por mais banal que seja, é nomeada como curadoria e os curadores mais valorizados pelo sistema de arte se dizem movidos, sobretudo, pela curiosidade, parece que chegamos num ponto de inflexão no que diz respeito à relevância do curador de arte. ${ }^{95}$ Cabe a qualquer curador que atue em um museu de arte hoje responder criticamente à complexidade das múltiplas dimensões do museu contemporâneo, sob o risco de ver sua função e seu papel social esvaziados de sentido.
94. Sobre o processo de descolonização em museus, Cf. Brulon (2020).

95. Stoppard (2020). 


\section{REFERÊNCIAS}

ALTSHULER, Bruce. The avant-garde in exhibition: new art in the 20th century. Nova York: Abrams, 1994.

ARANTES, Otília. Mário Pedrosa: itinerário crítico. São Paulo: Cosac Naify, 2004.

AVELAR, Ana. A raiz emocional: arte brasileira na crítica de Lourival Gomes Machado. São Paulo: Alameda, 2014.

BALZER, David. Curationism: how curating took over the art world and everything else. Londres: Pluto Press, 2015.

BARDI, Pietro Maria. The Arts in Brazil: a new museum in São Paulo. Milão: Edizione del Milione, 1956.

BARROSO, Gustavo. Introdução à técnica de museus: parte geral e parte básica. Rio de Janeiro: Gráfica Olímpica, 1946. v. 1.

BARROSO, Gustavo. Introdução à técnica de museus: parte especializada. Rio de Janeiro: Gráfica Olímpica, 1947. v. 2.

BATISTA, Marta Rossetti (org.). Coleção Mário de Andrade: religião e magia, música e dança, cotidiano. São Paulo: Edusp: IMESP, 2004.

BATISTA, Marta Rossetti; LIMA, Yone Soares de (orgs.). Coleção Mário de Andrade: artes plásticas. São Paulo: IEB-USP, 1998.

BELTING, Hans. Das ende der Kunstgeschichte? Berlim: Deutscher Kunstverlag, 1991.

BELTING, Hans. Likeness and presence: a history of the image before the era of art. Chicago: University of Chicago Press, 1997.

BENNETT, Tony. The birth of the museum: history, theory, politics. Londres: Routledge, 1995.

BISHOP, Claire. O que é um curador? A ascensão (e queda?) do curador autor. Concinnitas, Rio de Janeiro, v. 2, n. 27, p. 270-282, 2015.

BLOM, Philipp. A grandeza dos impérios. In: BLOM, Philipp. Ter e manter: uma história íntima de colecionadores e coleções. Rio de Janeiro: Record, 2003. p. 131-146.

BONAFOUX, Pascal. Le Musée du Luxembourg à Paris. Paris: Skira, 2006. 
BRANDÃO, Carlos Roberto Ferreira; COSTA, Cleide. Uma crônica da integração dos museus estatutários à USP. Anais do Museu Paulista, São Paulo, v. 15, n. 1, p. 207-217. 2007. DOI: 10.1590/ S0101-47142007000100005. Disponível em: <https://bit.ly/3mOVBji . Acesso em: 24 mar. 2021.

BRULON, Bruno. Descolonizar o pensamento museológico: reintegrando a matéria para repensar os museus. Anais do Museu Paulista, São Paulo, v. 28, p. 1-30, 2020. DOI: 10.1590/198202672020v28e1. Disponível em: <https://bit.ly/3sh4T8T>. Acesso em: 24 mar. 2021.

BRUSH, Kathryn. Vastly more than brick \& mortar: reinventing the Fogg Art Museum in the 1920s. New Haven: Yale University Press, 2004.

CAUQUELIN, Anne. Arte contemporânea: uma introdução. São Paulo: Martins Fontes, 2005.

CELANT, Germano (org.). When attitudes become form: Bern, 1969/Venice, 2013. Milão: Progetto Prada Arte, 2013.

CHIARELLI, Tadeu. Um jeca nos vernissages. São Paulo: Edusp, 1995.

CHIPP, Herschel B. Teorias da arte moderna. São Paulo: Martins Fontes, 1996.

COSTA, Helouise. Da fotografia como arte à arte como fotografia: a experiência do Museu de Arte Contemporânea da USP na década de 1970. Anais do Museu Paulista, São Paulo, v. 16, n. 2, p. 131-173, 2008. DOI: 10.1590/S0101-47142008000200005. Disponível em: <https://bit. ly/3abyPwZ>. Acesso em: 24 mar. 2021.

COSTA, Helouise. Metamorfoses da fotografia: entre o moderno e o contemporâneo. In: MAM 70, 1948-2018. São Paulo: MAM: MAC USP, 2018. p. 41-54.

CUNHA, Antônio Geraldo da. Dicionário etimológico da língua portuguesa. Rio de Janeiro: Lexicon, 2017.

DANTO, Arthur. After the end of art: contemporary art and the pale of history. Nova Jersey: Princeton University Press, 2014.

DIDI-HUBERMAN, Georges. Devant l'image: questions posées aux fins d'une histoire de l'art. Paris: Les Éditions de Minuit, 1990.

DROSTE, Magdalena. Bauhaus, 1919-1933. Berlim: Taschen, 2006.

DUNCAN, Sally Anne; MCCLELLAN, Andrew. The art of curating: Paul Sachs and the museum course at Harvard. Los Angeles: The Getty Research Institute, 2018.

FABRIS, Annateresa. Walter Zanini: o construtor do MAC USP. Rio de Janeiro: CBHA, 2009. 
FILIPOVIC, Elena; VAN HAL, Marieke; ØVSTEB $\varnothing$, Solveig (orgs.). The Biennial reader. Ostfildern: Hatje Cantz, 2010.

FOWLE, Kate. Who cares? Understanding the role of the curator today. In: RAND, Steven; KOURIS, Heather (orgs.). Cautionary tales: critical curating. Nova York: Apexart, 2007. p. 26-35.

FRANÇOZO, Mariana de Campos. De Olinda a Holanda: o gabinete de curiosidades de Nassau. Campinas: Unicamp, 2014.

GLEIS, Ralph. Caillebotte: painter and patron of Impressionism. Londres: Hirmer Publishers, 2019.

GLICENSTEIN, Jérôme. L'Art: une histoire d'expositions. Paris: Presses Universitaires de France, 2012.

GONÇALVES, Lisbeth Rebollo. Sérgio Milliet: crítico de arte. São Paulo: Edusp, 1992.

HAAG, Sabine (org.). Sammellust: die galerie erzherzog leopold wilhelms. Viena: KHM Kunsthistorisches Museum, 2014.

HASKELL, Francis. The ephemeral museum: old masters paintings and the rise of the art exhibition. New Haven: Yale University Press, 2000.

HAXHIRAJ, Marinella. Ulisse Aldrovandi: Il museografo. Bologna: Bononia University Press, 2016.

HEINICH, Nathalie; POLLACK, Michael. Du conservateur de musée à l'auteur d'exposition: l'invention d'une position singulière. Sociologie du Travail, Lyon, v. 31, n. 1, p. 29-49, 1989.

HOOPER GREENHILL, Eileen. Museums and the shaping of knowledge. Londres: Routledge, 1992.

HUSSLEIN-ARCO, Agnes; SCHOELLER, Katharina (eds.). Das Belvedere: Genese eines Museums. Viena: Bibliothek der Provinz, 2011.

JALLAGEAS, Neide; LIMA, Celso. Vkhutemas: o futuro em construção (1918-2018). São Paulo: Sesc Pompeia, 2018.

KANTOR, Sybil Gordon. Alfred H. Barr, Jr: and the intellectual origins of the museum of modern art. Cambridge: The MIT Press, 2002.

LAFUENTE, Pablo; MCEVILLEY, Thomas; BUCHLOH, Benjamin; ARAEEN, Rasheed; MARTIN, Jean-Hubert (eds.). Making art global (part 2): Magiciens de la Terre 1989. Londres: Afterall Books, 2013. 
LEITE, Andréa Andira. A experiência do Departamento de Informação e Documentação Artísticas (IDART) em São Paulo: uma revisão crítica. 2017. Dissertação (Mestrado em Museologia) - Universidade de São Paulo, São Paulo, 2017.

LEON, Ethel. IAC/MASP: uma escola futurista para São Paulo. In: MAGALHÃES, Ana Gonçalves; RUSCONI, Paolo; MIGLIACCIO, Luciano (orgs.). Modernidade latina: os italianos e os centros do modernismo latino-americano. São Paulo: MAC USP, 2013. p. Disponível em: <https://bit. ly/32fM9fK>. Acesso em: 24 mar. 2021.

LEON, Ethel. IAC: primeira escola de design do Brasil. São Paulo: Blucher, 2014.

LOURENÇO, Marta C. A contribution to the history of university museums and collections in Europe. In: INTERNATIONAL COUNCIL OF MUSEUMS, 2002, Sidney. Anais [...]. Sidney: UMAC, 2002. Disponível em: <https://bit.ly/3tU1kXv>. Acesso em: 20 mar. 2020.

MACHADO, Lourival Gomes. Retrato da arte moderna do Brasil. São Paulo: Departamento de Cultura, 1947.

MAGALHÃES, Ana Gonçalves; BEIGUELMAN, Giselle (orgs.). Futuros possíveis: arte, museus e arquivos digitais. São Paulo: Peirópolis, 2014.

MAGALHÃES, Ana Gonçalves. Classicismo moderno: Margherita Sarfatti e a pintura italiana no acervo do MAC USP. São Paulo: Alameda Editorial, 2016.

MAGALHÃES, Ana Gonçalves. Expor e colecionar: a formação de acervos de arte moderna e contemporânea entre o MAM e o MAC USP. In: MAM 70, 1948-2018. São Paulo: MAM: MAC USP, 2018. p. 25-40.

MAGAlHÃES, Ana Gonçalves. Museu universitário ou museu na universidade? O caso do Museu de Arte Contemporânea da Universidade de São Paulo (MAC USP). In: OLIVEIRA, Emerson Dionísio de; COUTO, Maria de Fátima Morethy; MALTA, Marize (orgs.). História da arte em museus. Rio de Janeiro: Rio Books, 2020. p. 179-186.

MAIA NETO, Renato de Andrade. Arquiteturas para o Museu de Arte Contemporânea da USP. 2004. Tese (Doutorado em Arquitetura e Urbanismo) - Universidade de São Paulo, São Paulo, 2004.

MCCLELLAN, Andrew. The Art Museum from Boullée to Bilbao. Londres: University of California Press, 2008.

MCGREGOR, Arthur. The Ashmolean Museum: a brief history of the museum and its collections. Oxford: Ashmolean Museum, 2001.

MENESES, Ulpiano Bezerra de. Do teatro da memória ao laboratório da história: a exposição museológica e o conhecimento histórico. Anais do Museu Paulista, São Paulo, v. 2 p. 9-42, 1994. DOI: 10.1590/S0101-47141994000100002. Disponível em: <https://bit.ly/3mOfes7>. Acesso em: 24 mar. 2021. 
MICELI, Sergio; MATTOS, Franklin de (orgs.). Gilda, a paixão pela forma. São Paulo: Ouro sobre Azul: Fapesp, 2007.

MIGUEL, Jair Diniz. Arte, ensino, utopia e revolução: os ateliês artísticos Vkhutemas/Vkhteir (Rússia/URSS, 1920-1930). 2006. Tese (Doutorado em História Social) - Faculdade de Filosofia, Letras e Ciências Humanas, Universidade de São Paulo, São Paulo, 2006.

MITCHELL, W. J. T. What do pictures want? The lives and loves of images. Chicago: University of Chicago Press, 2013.

NASCIMENTO, Ana Paula. São Paulo: meio artístico e as exposições (1895-1929). In: VALLE, Arthur; DAZZI, Camila (orgs.). Oitocentos: arte brasileira do Império à República. Rio de Janeiro: UFRJ: Dezenovevinte, 2010. p. 71-84.

NELSON, Robert S.; SHIFF, Richard. Critical terms for art history. Chicago: University of Chicago Press, 1996.

OBRIST, Hans Ulrich. Caminhos da curadoria. Rio de Janeiro: Editora Cobogó, 2014.

O’DOHERTY, Brian. No interior do cubo branco. São Paulo: Martins Fontes, 2002.

OLIVA, Fernando Augusto. Um crítico em mutação: Frederico Morais e a arte brasileira em três momentos. 2017. Tese (Doutorado em Artes Visuais) - Escola de Comunicações e Artes, Universidade de São Paulo, São Paulo, 2017.

O'NEIL, Paul. The emergence of curatorial discourse from the late 1960s to the present. In: O'NEIL, Paul. The culture of curating and the curating of culture(s). Cambridge: The MIT Press, 2016a. p. 9-50.

O'NEIL, Paul. Mobility as a prerequisite of curatorship in the twenty-first century. In: O'NEIL, Paul. The culture of curating and the curating of culture(s). Cambridge: The MIT Press, 2016b. p. 73-78.

ORCUTT, Kimberly A. Personal collecting meets institutional vision. Journal of the History of Collections, Oxford, v. 18, n. 2, p. 267-284, 2006.

OSTEN, Marion von; WATSON, Grant. Bauhaus imaginista: aprendizados recíprocos. São Paulo: Sesc Pompéia, 2019.

PEDROSA, Adriano; PROENÇA, Luíza (orgs.). Concreto e cristal: o acervo do MASP nos cavaletes de Lina Bo Bardi. Rio de Janeiro: Editora Cobogó, 2015.

PEDROSA, Mário. O novo MAM terá cinco museus. Jornal do Brasil, Rio de Janeiro, 15 set. 1978.

PEDROSA, Mário. Parecer sobre o core da Cidade Universitária. Risco, São Carlos, n. 2, p. 67-73, 2003. 
PHILLIPS, Glenn; KAISER, Philipp. Harald Szeemann: Museum of Obsessions. Los Angeles: Getty Publications, 2018.

POINSOT, Jean Marc. Quand l'oeuvre a lieu: l'art exposé et ses récits autorisés. Paris: Le Presses du Réel, 1993.

PONTES, Heloisa. A paixão pelas formas: Gilda de Mello e Souza. Novos Estudos Cebrap, São Paulo, n. 74, p. 87-105, 2006.

ROCHA, Claudia Regina Alves da. Da pinacoteca ao museu: historicizando processos museológicos. 2014. Dissertação (Mestrado em Museologia) - Universidade de São Paulo, São Paulo, 2014.

SEHN, Magali Melleu. Entre resíduos e dominós: preservação de instalações de arte no Brasil. Belo Horizonte: Editora C/Arte, 2014.

SQUEFF, Letícia. O Brasil nas letras de um pintor. Campinas: Editora da Unicamp, 2004.

SQUEFF, Letícia. Revendo a Missão Francesa: a missão artística de 1816, de Alphonse d'Escragnolle Taunay. In: ENCONTRO DE HISTÓRIA DA ARTE, 1., 2005, Campinas. Anais [...]. Campinas: IFCH-Unicamp, 2005. p. 133-140.

SQUEFF, Letícia. Uma galeria para o Império: a Coleção Escola Brasileira e as origens do Museu Nacional de Belas Artes. São Paulo: Edusp, 2012.

STANISZEWSKI, Mary Anne. The power of display: a history of exhibition installations at the museum of modern art. Cambridge: The MIT Press, 1999.

STOPPARD, Lou. Everyone's a curator now. The New York Times, New York, 3 mar. 2020. Disponível em: <https://nyti.ms/2QFUHtP>. Acesso em: 24 mar. 2021.

STRAUSS, David Levi. The Bias of the world: curating after Szeemann \& Hopps. The Brooklyn Rail, New York, 2007. Disponível em: <https://bit.ly/3114JCo>. Acesso em: 25 mar 2021.

TEJO, Cristiana Santiago. A gênese do campo da curadoria de arte no Brasil: Aracy Amaral, Frederico Morais e Walter Zanini. 2017. Tese (Doutorado em Sociologia) - Universidade Federal de Pernambuco, Recife, 2017.

TELLES, Patrícia D. O Cavaleiro Brito e o Conde da Barca: dois diplomatas portugueses e a Missão Francesa de 1816 ao Brasil. Lisboa: Documenta, 2017.

THE HARVARD ART MUSEUMS. Director's report (Harvard University Art Museums). Harvard University Museums, Cambridge, n. 1987, p. 54-58, 1988. 
URSPRUNG, Philip; OBRIST, Hans Ulrich. "Curiosity is the motor of the entire interview project": Hans Ulrich Obrist in conversation with Philip Ursprung. The Art Bulletin, New York, v. 94, n. 1, p. 42-49, 2012.

VALLE, Arthur. Instalação nas Exposições Gerais de Belas Artes durante a 1a República. 19E20, Rio de Janeiro, v. 6, n. 1, 2011. Disponível em: <https://bit.ly/31Pmkfr>. Acesso em: 25 mar. 2021.

VAN CALERBERGEN, Ernst Velingen (ed.). David Teniers and the Theatre of Painting. Londres: Courtauld Institute Art Gallery, 2006.

WARNKE, Martin. O artista da corte: os antecedentes do artista moderno. São Paulo: Edusp, 2001.

WATERFIELD, Giles. Teniers's Theatrum Pictorium: its genesis and its influence. In: KLINGE, Margret. David Teniers and the theatre of painting. Londres: Paul Holberton Publishing, 2006. p. 41-57.

ZANINI, Walter. História geral da arte no Brasil. São Paulo: Instituto Moreira Salles: Fundação Djalma Guimarães, 1983.

ZANINI, Walter. Problemas museológicos. O Estado de S. Paulo, São Paulo, 4 jan. 1964. Suplemento Literário, p. 40.

ZANINI, Walter. Considerações preliminares sobre a história da arte no Brasil. In: FREIRE, Cristina (org.). Walter Zanini: escrituras críticas. São Paulo: Annablume, 2013. p. 306-311.

ZEN, Daniel Dalla. O curso de museus e a museologia no Brasil. Revista Eletrônica Ventilando Acervos, Florianópolis, v. 3, n. 1, p. 76-91. Disponível em: <https://bit.ly/39bVDfG >. Acesso em: 25 mar. 2021.

SITES

CONSEIL INTERNATIONAL DES MUSÉES. Histoire de l'ICOM. ICOM, Paris, 2019. Disponível em: <https://bit.ly/39hktL5>. Acesso em: 20 maio 2020.

INSTITUT NATIONAL D'HISTOIRE DE L'ART. DENON, Dominique Vivant. INHA, Paris, 2019. Disponível em: <https://bit.ly/3m3yK3v>. Acesso em: 23 maio 2019.

MUSÉE DU LOUVRE. Organigramme du Musée du Louvre. Musée du Louvre, Paris, 2019. Disponível em: <https://bit.ly/3ckUGUe>. Acesso em: 23 maio 2019.

Artigo apresentado em: 25/08/2020. Aprovado em: 10/10/2020. (cc) BY

All the contents of this journal, except where otherwise noted, is licensed under a Creative Commons Attribution License 